This PDF is a selection from an out-of-print volume from the National Bureau of Economic Research

Volume Title: National Saving and Economic Performance

Volume Author/Editor: B. Douglas Bernheim and John B. Shoven, editors

Volume Publisher: University of Chicago Press

Volume ISBN: 0-226-04404-1

Volume URL: http://www.nber.org/books/bern91-2

Conference Date: January 6-7, 1989

Publication Date: January 1991

Chapter Title: Quantifying International Capital Mobility in the 1980s

Chapter Author: Jeffrey A. Frankel

Chapter URL: http://www.nber.org/chapters/c5993

Chapter pages in book: (p. 227 - 270) 


\title{
Quantifying International Capital Mobility in the 1980s
}

\author{
Jeffrey A. Frankel
}

Feldstein and Horioka upset conventional wisdom in 1980 when they concluded that changes in countries' rates of national saving had a very large effect on their rates of investment, and interpreted this finding as evidence of low capital mobility. Although their regressions have been subject to a great variety of criticisms, their basic finding seems to hold up. But does it imply imperfect capital mobility?

Let us begin by asking why we would ever expect a shortfall in one country's national saving not to reduce the overall availability of funds and thereby crowd out investment projects that might otherwise be undertaken in that country. After all, national saving and investment are linked through an identity. (The variable that completes the identity is, of course, the current account balance.)

The aggregation together of all forms of "capital" has caused more than the usual amount of confusion in the literature on international capital mobility. Nobody ever claimed that international flows of foreign direct investment were large enough that a typical investment project in the domestic country would costlessly be undertaken directly by a foreign company when there was a shortfall in domestic saving. ${ }^{1}$ Rather, the argument was that the typical American corporation could borrow at the going interest rate in order to finance its investment projects and, if the degree of capital mobility was sufficiently high, the going interest rate would be tied down to the world interest rate by international flows of portfolio capital. If portfolio capital were a perfect substitute for physical capital, then the difference would be immaterial; but the two types of capital probably are not in fact perfect substitutes.

This paper examines a number of alternative ways of quantifying the degree

Jeffrey Frankel is professor of economics, University of California, Berkeley, and research associate, National Bureau of Economic Research. 
of international capital mobility. One conclusion is that the barriers to crossborder flows are sufficiently low that, by 1989 , financial markets can be said to be virtually completely integrated among the large industrial countries (and among some smaller countries as well). But this is a different proposition from saying that real interest rates are equalized across countries, which is still different from saying that investment projects in a country are unaffected by a shortfall in national saving. We will see that there are several crucial links that can, and probably do, fail to hold.

In many cases, notably the United Kingdom and Japan (and perhaps now Italy and France as well), the finding of high integration with world financial markets is a relatively new one, attributable to liberalization programs over the last 10 years. Even in the case of financial markets in the United States, integration with the Euromarkets appears to have been incomplete as recently as $1982 .{ }^{2}$ An important conclusion of this paper for the United States is that the current account deficits of the 1980s have been large enough, and by now have lasted long enough, to reduce significantly estimates of the correlation between saving and investment. The increased degree of worldwide financial integration since 1979 is identified as one likely factor that has allowed such large capital flows to take place over the past decade. But even if U.S. interest rates are now viewed as tied to world interest rates, ${ }^{3}$ there are still other weak links in the chain. The implication is that crowding out of domestic investment can still take place.

\subsection{Four Alternative Definitions of International Capital Mobility}

By the second half of the 1970s, international economists had come to speak of the world financial system as characterized by perfect capital mobility. In many ways, this was "jumping the gun." It is true that financial integration had been greatly enhanced after 1973 by the removal of capital controls on the part of the United States, Germany, Canada, Switzerland, and the Netherlands; by the steady process of technical and institutional innovation, particularly in the Euromarkets; and by the recycling of OPEC surpluses to developing countries. But almost all developing countries retained extensive restrictions on international capital flows, as did a majority of industrialized countries. Even among the five major countries without capital controls, capital was not perfectly mobile by some definitions.

There are at least four distinct definitions of perfect capital mobility that are in widespread use. (1) The Feldstein-Horioka definition: exogenous changes in national saving (i.e., in either private savings or government budgets) can be easily financed by borrowing from abroad at the going real interest rate, and thus need not crowd out investment in the originating country (except perhaps to the extent that the country is large in world financial markets). (2) Real interest parity: International capital flows equalize real interest rates 
across countries. (3) Uncovered interest parity: Capital flows equalize expected rates of return on countries' bonds, despite exposure to exchange risk. (4) Closed interest parity: Capital flows equalize interest rates across countries when contracted in a common currency. These four possible definitions are in ascending order of specificity. Only the last condition is an unalloyed criterion for capital mobility in the sense of the degree of financial market integration across national boundaries. ${ }^{4}$

As we will see, each of the first three conditions, if it is to hold, requires an auxiliary assumption in addition to the condition that follows it. Uncovered interest parity requires not only closed (or covered) interest parity, but also the condition that the exchange risk premium is zero. Real interest parity requires not only uncovered interest parity, but also the condition that expected real depreciation is zero. The Feldstein-Horioka condition requires not only real interest parity, but also a certain condition on the determinants of investment. But even though the relevance to the degree of integration of financial markets decreases as auxiliary conditions are added, the relevance to questions regarding the origin of international payments imbalances increases. We begin our consideration of the various criteria of capital mobility with the FeldsteinHorioka definition.

\subsection{Feldstein-Horioka Tests}

The Feldstein-Horioka definition requires that the country's real interest rate is tied to the world real interest rate by criterion 2 ; it is, after all, the real interest rather than the nominal on which saving and investment in theory depend. But for criterion 1 to hold, it is also necessary that any and all determinants of a country's rate of investment other than its real interest rate be uncorrelated with its rate of national saving. Let the investment rate be given by

$$
(I / Y)_{i}=a-b r_{i}+u_{i},
$$

where $I$ is the level of capital formation, $Y$ is national output, $r$ is the domestic real interest rate, and $u$ represents all other factors, whether quantifiable or not, that determine the rate of investment. Feldstein and Horioka (1980) regressed the investment rate against the national saving rate,

$$
(I / Y)_{i}=A+B(N S / Y)_{i}+v_{i},
$$

where $N S$ is private saving minus the budget deficit. To get the zero coefficient $B$ that they were looking for requires not only real interest parity:

$$
r_{i}-r^{*}=0
$$

(with the world interest rate $r^{*}$ exogenous or in any other way uncorrelated with $\left.[N S / Y]_{i}\right)$ but also a zero correlation between $u_{i}$ and $(N S / Y)_{i}$. 


\subsubsection{The Saving-Investment literature}

Feldstein and Horioka's finding that the coefficient $B$ is in fact closer to one than to zero has been reproduced many times. Most authors have not been willing, however, to follow them in drawing the inference that financial markets are not highly integrated. There have been many econometric critiques, falling into two general categories.

Most commonly made is the point that national saving is endogenous or, in our terms, is correlated with $\boldsymbol{u}_{i}$. This will be the case if national saving and investment are both procyclical, as they are in fact known to be, or if they both respond to the population or productivity growth rates. ${ }^{5}$ It will also be the case if governments respond endogenously to incipient current account imbalances with policies to change public (or private) saving in such a way as to reduce the imbalances. This "policy reaction" argument has been made by Fieleke (1982), Tobin (1983), Westphal (1983), Caprio and Howard (1984), Summers (1988), Roubini (1988) and Bayoumi (1989). But Feldstein and Horioka made an effort to handle the econometric endogenity of national saving, more so than have some of their critics. To handle the cyclical endogeneity, they computed averages over a long enough period of time that business cycles could be argued to wash out. To handle other sources of endogeneity, they used demographic variables as instrumental variables for the saving rate.

The other econometric critique is that if the domestic country is large in world financial markets, $r^{*}$ will not be exogenous with respect to $(N S / Y)_{i}$, and therefore even if $r=r^{*}, r$ and in turn $(I / Y)_{i}$ will be correlated with $(N S / Y)_{i}$. In other words, a shortfall in domestic savings will drive up the world interest rate, and thus crowd out investment in the domestic country as well as abroad. This "large-country" argument has been made by Murphy (1984) and Tobin (1983). An insufficiently appreciated point is that the large-country argument does not create a problem in cross-section studies, because all countries share the same world interest rate $r^{*}$. Since $r^{*}$ simply goes into the constant term in a cross-section regression, it cannot be the source of any correlation with the right-hand-side variable. The large-country problem cannot explain why the countries that are high-saving relative to the average tend to coincide with the countries that are high-investing relative to the average. ${ }^{6}$

If the regressions of saving and investment rates were a good test for barriers to financial market integration, one would expect to see the coefficient falling over time. Until now, the evidence has if anything showed the coefficient rising over time rather than falling. This finding has emerged both from cross-section studies, which typically report pre- and post-1973 resultsFeldstein (1983), Penati and Dooley (1984), and Dooley, Frankel and Mathieson (1987) - and from pure time-series studies-Obstfeld $(1986,1989)^{7}$ and Frankel (1986) for the United States. The econometric endogeneity of national saving does not appear to be the explanation for this finding, because it holds equally well when instrumental variables are used. ${ }^{8}$ 
The easy explanation for the finding is that, econometric problems aside, real interest parity-criterion 2 above-has not held any better in recent years than it did in the past. Mishkin (1984a, 1352), for example, found even more significant rejections of real interest parity among major industrialized countries for the floating rate period after the second quarter of 1973 (1973/II) than he did for his entire 1967/II to 1979/II sample period. Caramazza et al. (1986, 43-47) also found that some of the major industrialized countries in the 1980s (January 1980 through June 1985) moved farther from real interest parity than they had been in the 1970s (July 1973 through December 1979). ${ }^{9}$ In the early 1980 s, the real interest rate in the United States, in particular, rose far above the real interest rate of its major trading partners, by any of a variety of measures. ${ }^{10}$ If the domestic real interest rate is not tied to the foreign real interest rate, then there is no reason to expect a zero coefficient in the savinginvestment regression. We discuss in a later section the factors underlying real interest differentials.

\subsubsection{The U.S. Saving-Investment Regression Updated}

Since 1980 the massive fiscal experiment carried out under the Reagan administration has been rapidly undermining the statistical finding of a high saving-investment correlation for the case of the United States. The increase in the structural budget deficit, which was neither accommodated by monetary policy nor financed by an increase in private saving, reduced the national saving rate by 3 percent of GNP, relative to the 1970s. The investment ratewhich at first, like the saving rate, fell in the 1981-82 recession-in the late 1980s approximately reattained its 1980 level at best. ${ }^{11}$ The saving shortfall was made up, necessarily, by a flood of borrowing from abroad equal to more than 3 percent of GNP. Hence the current account deficit of $\$ 161$ billion in 1987. By contrast, the U.S. current account balance was on average equal to zero in the 1970s.

By now, the divergence between U.S. national saving and investment has been sufficiently large and long lasting to show up in longer-term regressions of the Feldstein-Horioka type. If one seeks to isolate the degree of capital mobility or crowding out for the United States in particular, and how it has changed over time, then time-series regression is necessary (whereas if one is concerned with such measures worldwide, then cross-section regressions of the sort performed by Feldstein and Horioka are better). Table 8.1 reports instrumental variables regressions of investment against national saving for the United States from 1870 to $1987 .{ }^{12}$ Decade averages are used for each variable, which removes some of the cyclical variation but gives us only 12 observations. (Yearly data are not in any case available before 1930.) That is one more observation than was available in Frankel (1986, table 2.2), which went only through the 1970 s.

As before, the coefficient is statistically greater than zero and is not statistically different from one, suggesting a high degree of crowding out (or a low 
Table 8.1

The "Feldstein-Horioka Coefficient" by Decades, 1869-1987; Instrumental Variables Regression of U.S. Investment against National Saving (as shares of GNP)

\begin{tabular}{|c|c|c|c|c|c|}
\hline Constant & Coefficient & $\begin{array}{l}\text { Time Trend } \\
\text { in Coefficient }\end{array}$ & $\begin{array}{l}\text { Durbin-Watson } \\
\text { Statistic }\end{array}$ & $\begin{array}{c}\text { Autoregressive } \\
\text { Parameter }\end{array}$ & $R^{2}$ \\
\hline 1. $\begin{array}{c}.411 \\
(1.340)\end{array}$ & $\begin{array}{l}.976 \\
(.086)\end{array}$ & & 1.45 & & .96 \\
\hline 2. $\begin{array}{c}3.324 \\
(1.842)\end{array}$ & $\begin{array}{l}.785 \\
(.118)\end{array}$ & & & $\begin{array}{l}.46 \\
(.33)\end{array}$ & .97 \\
\hline 3. $\begin{array}{c}3.291 \\
(6.176)\end{array}$ & $\begin{array}{l}.854 \\
(.279)\end{array}$ & $\begin{array}{r}-.011 \\
(.21)\end{array}$ & .73 & & .92 \\
\hline 4. $\begin{array}{c}1.061 \\
(1.507)\end{array}$ & $\begin{array}{c}.924 \\
(.093)\end{array}$ & $\begin{array}{c}.001 \\
(.005)\end{array}$ & & $\begin{array}{c}.03 \\
(.08)\end{array}$ & .96 \\
\hline
\end{tabular}

Note: Instrumental variables are dependency ratio and military expenditure/GNP.

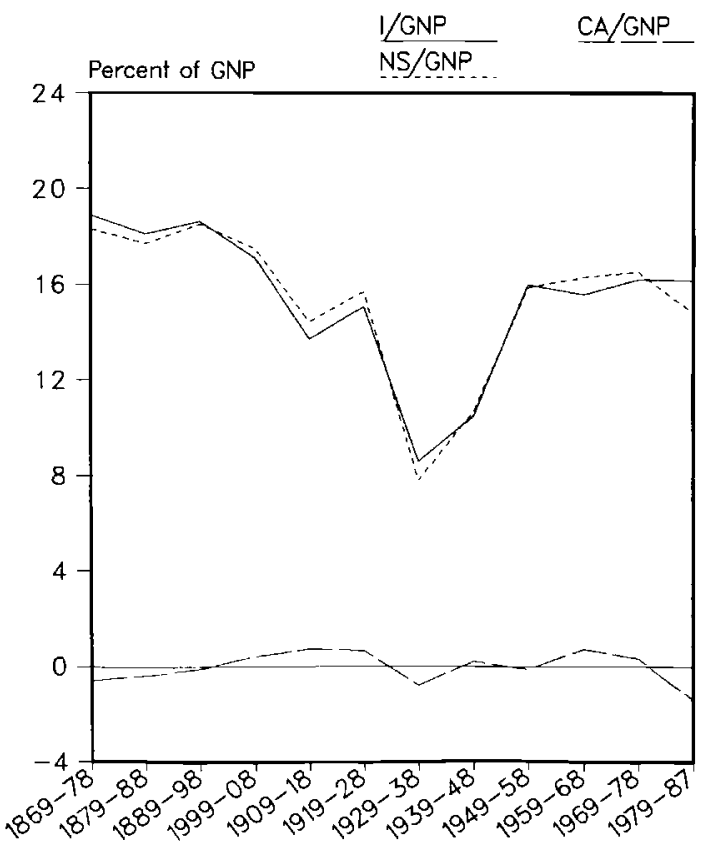

Fig. 8.1 U.S. national saving (private saving plus government budget surplus), investment, and current account: 10-year averages

degree of capital mobility, in Feldstein and Horioka's terms). But the point estimate of the coefficient (when correcting for possible serial correlation) drops from .91 in the earlier study to .79 . We can allow for a time trend in the coefficient; it drops from plus .01 a year in the earlier study to minus .01 a year (or plus .001, when correcting for serial correlation) in the longer 
sample. Thus the additional years $1980-87$ do show up as anticipated: as exhibiting a lower U.S. degree of crowding out, even if the change is small. (The trend is not statistically significant, but this is not surprising given the small number of observations.)

A date set that begins later would seem more promising than the 12 decade averages. Table 8.2 reports regressions for yearly data beginning in 1930 . Much of the variation in the yearly data is cyclical, so table 8.3 uses saving and investment rates that have been cyclically adjusted, for a sample period

Table 8.2 The "Feldstein-Horioka Coefficient" by Years, 1929-87;

Instrumental Variables Regression of U.S. Investment against National Saving (as shares of GNP), Comparing Regressions Before and After 1980

\begin{tabular}{|c|c|c|c|c|c|}
\hline & Constant & Coefficient & $\begin{array}{l}\text { Durbin-Watson } \\
\text { Statistic }\end{array}$ & $\begin{array}{l}\text { Autoregressive } \\
\text { Parameter }\end{array}$ & $R^{2}$ \\
\hline $1929-87$ & $\begin{array}{l}2.99 \\
(.88)\end{array}$ & $\begin{array}{c}.79 \\
(.06)\end{array}$ & .64 & & .94 \\
\hline $1930-87$ & $\begin{array}{c}4.85 \\
(2.61)\end{array}$ & $\begin{array}{c}.67 \\
(.19)\end{array}$ & & $\begin{array}{l}.77 \\
(.09)\end{array}$ & .89 \\
\hline $1929-79$ & $\begin{array}{l}1.89 \\
(.61)\end{array}$ & $\begin{array}{l}.86 \\
(.04)\end{array}$ & 1.31 & & .97 \\
\hline $1930-79$ & $\begin{array}{l}2.00 \\
(.66)\end{array}$ & $\begin{array}{l}.85 \\
(.05)\end{array}$ & & $\begin{array}{l}.38 \\
(.13)\end{array}$ & .95 \\
\hline $1980-87$ & $\begin{array}{l}13.73 \\
(3.85)\end{array}$ & $\begin{array}{l}.15 \\
(.27)\end{array}$ & 2.09 & & \\
\hline $1981-87$ & $\begin{array}{l}-.36 \\
(.56)\end{array}$ & $\begin{array}{c}.03 \\
(.02)\end{array}$ & & $\begin{array}{c}-.37 \\
\text { Not Converged }\end{array}$ & .00 \\
\hline
\end{tabular}

Table 8.3 The "Feldstein-Horioka Coefficient" by Years, 1955-87:

Instrumental Variables Regression of U.S. Investment against

National Saving (as shares of GNP and cyclically adjusted)

\begin{tabular}{|c|c|c|c|c|c|}
\hline & Constant & Coefficient & $\begin{array}{l}\text { Durbin-Watson } \\
\text { Statistic }\end{array}$ & $\begin{array}{l}\text { Autoregressive } \\
\text { Parameter }\end{array}$ & $R^{2}$ \\
\hline $1929-87$ & a & $\begin{array}{l}-.06 \\
(.25)\end{array}$ & .96 & & .25 \\
\hline $1930-87$ & a & $\begin{array}{c}.03 \\
(.26)\end{array}$ & & $\begin{array}{l}.50 \\
(.15)\end{array}$ & .42 \\
\hline $1929-79$ & $\begin{array}{l}-.68 \\
(.17)\end{array}$ & $\begin{array}{l}1.37 \\
(.23)\end{array}$ & 1.61 & & .73 \\
\hline $1930-79$ & $\begin{array}{c}-.57 \\
(.18)\end{array}$ & $\begin{array}{l}1.05 \\
(.19)\end{array}$ & & $\begin{array}{l}.35 \\
(.20)\end{array}$ & .70 \\
\hline $1980-87$ & $\begin{array}{l}.39 \\
(.36)\end{array}$ & $\begin{array}{l}.13 \\
(.17)\end{array}$ & 2.46 & & .30 \\
\hline $1981-87$ & $\begin{array}{l}.58 \\
(.37)\end{array}$ & $\begin{array}{l}.22 \\
(.16)\end{array}$ & & $\begin{array}{c}-.13 \\
(.41)\end{array}$ & .34 \\
\hline
\end{tabular}

"Constant term is automaticallly zero because cyclically adjusted rates are residuals from a 195587 regression against the GNP gap. 


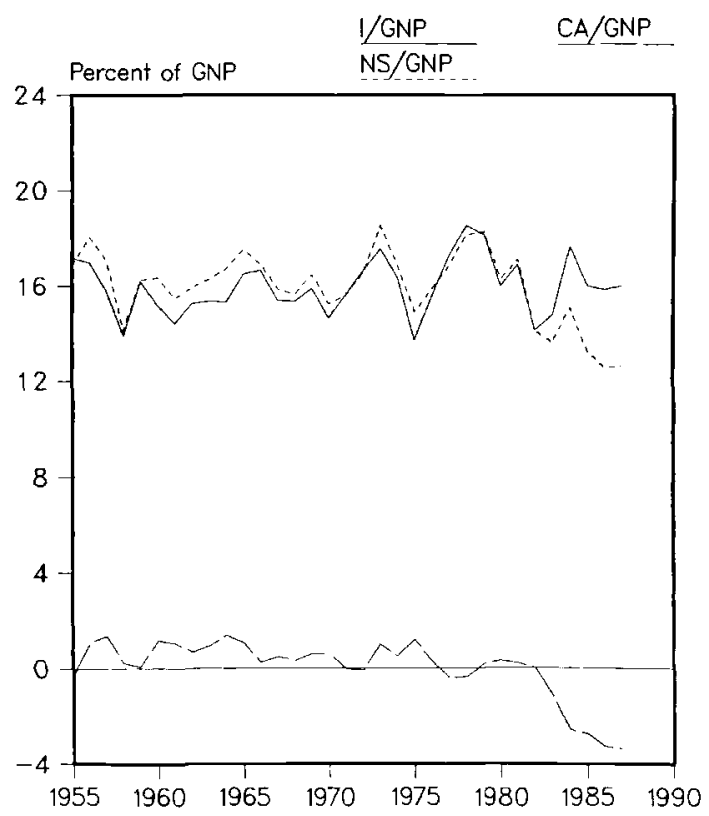

Fig. 8.2 U.S. national saving, investment, and current account

that begins in 1955. The cyclical adjustment of each is accomplished by first regressing it on the GNP gap, defined as the percentage deviation from the Bureau of Economic Analysis's "middle expansion trend" of GNP, and taking the residuals.

In previous work with a sample period of $1956-84$, the coefficient in a regression of cyclically adjusted saving and investment rates was estimated at .80 , statistically indistinguishable from 1 (Frankel 1986, 43-44). But now the coefficient has dropped essentially to zero, suggesting a zero degree of crowding out, or a zero degree of "saving retention" (or, in the FeldsteinHorioka terminology, "perfect capital mobility"). This finding is the result of the addition to the sample of another three years of record current account deficits, 1985-87, a period also in which the cyclically adjusted national saving rate was historically low. When the equation is estimated with an allowance for a time trend in the coefficient, the trend is negative (though statistically insignificant), whereas the earlier sample that stopped in 1984 showed a time trend that was positive (and insignificant).

To verify that the 1980s experience is indeed the source of the precipitous fall in the saving-investment coefficient,,$^{13}$ the sample period is split at 1980. For the period 1955-79, not only is the coefficient statistically indistinguishable from one, but the point estimate is slightly over one. ${ }^{14}$ It is clearly the unprecedented developments of the present decade that have overturned the hitherto-robust saving-investment relationship for the case of the United 
States. It is likely that financial liberalization in Japan, the United Kingdom, and other countries, and continued innovation in the Euromarkets (and perhaps the 1984 repeal of the U.S. withholding tax on borrowing from abroad), have resulted in a higher degree of capital mobility and thereby facilitated the record flow of capital to the United States in the 1980s. But the magnitude of the inflow is in the first instance attributable to the unprecedented magnitude of the decline in national saving. ${ }^{15}$

\subsection{Differentials in Expected Rates of Return, and Expected Real Depreciation}

If the goal is to measure the degree of integration of capital markets, rather than the degree to which decreases in national saving have crowded out investment, then it is better to look at differences in rates of return across countries rather than looking at saving-investment correlations. ${ }^{16}$ But measuring real interest differentials will not do the trick. An international investor, when deciding what country's assets to buy, will not compare the interest rates in different countries each expressed in terms of expected purchasing power over that country's goods. When he or she thinks to evaluate assets in terms of purchasing power, all assets will be evaluated in terms of the same basket, the one consumed by that particular investor. The expected inflation rate then drops out of differentials in expected rates of return among assets.

The differential in expected rates of return on two countries' bonds is the uncovered interest differential, the nominal interest differential minus the expected change in the exchange rate: $i-i^{*}-\left(\Delta s^{e}\right)$. If asset demands are highly sensitive to expected rates of return, then the differential will be zero, which gives us uncovered interest parity:

$$
i-i^{*}-\left(\Delta s^{e}\right)=0 .
$$

To distinguish this parity condition, which is criterion 3 above, from the other definitions, it has often been designated "perfect substitutability": not only is there little in the manner of transactions costs or government-imposed controls to separate national markets, but also domestic currency and foreign currency bonds are perfect substitutes in investors' portfolios.

Just as criterion 1 is considerably stronger than criterion 2, so is criterion 2 considerably stronger than criterion 3 . For real interest parity to hold, one must have not only uncovered interest parity, but an additional condition as well, which is sometimes called ex ante relative purchasing power parity:

$$
\Delta s^{e}=\Delta p^{e}-\Delta p^{e *} .
$$

Equation ( $\left(2^{\prime}\right)$ and equation (3) together imply equation (2). If goods markets are perfectly integrated, meaning not only that there is little in the manner of transportation costs or government-imposed barriers to separate national markets, but also that domestic and foreign goods are perfect substitutes in con- 


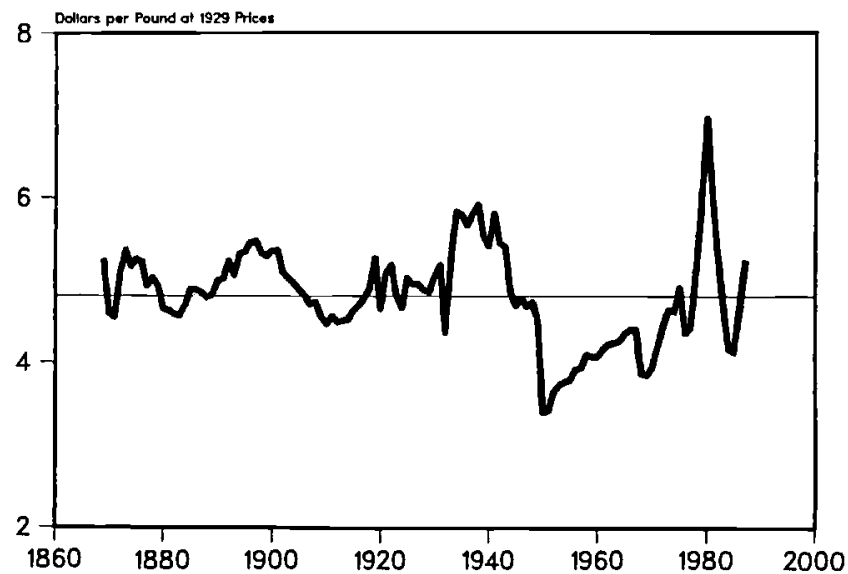

Fig. 8.3 Dollar/pound real exchange rate, 1869-1987, with period average

sumers' utility functions, then purchasing power parity holds. Purchasing power parity (PPP) in turn implies (2'). But as is by now well known, goods markets are not in fact perfectly integrated. Because of the possibility of expected real depreciation, real interest parity can fail even if criterion (3) holds perfectly. The remainder of this section considers the question of whether ex ante relative PPP, equation $\left(2^{\prime}\right)$, holds.

The enormous real appreciation of the dollar in the early 1980 s and subsequent real depreciation have by now convinced the remaining doubters, but abundant statistical evidence against PPP was there all along. Krugman (1978, 406), for example, computed for the floating rate period July 1973 through December 1976 standard deviations of the (logarithmic) real exchange rate equal to 6.0 percent for the pound/dollar rate and 8.4 percent for the mark/dollar rate. He also computed serial correlation coefficients for PPP deviations of .897 and .854 , respectively, on a monthly basis, equal to .271 and .150 on an annual basis. The serial correlation coefficient is of interest because it is equal to one minus the speed of adjustment to PPP. It may be best not to rely exclusively on the standard deviation of the real exchange rate as a summary statistic for the degree of integration of goods markets, because it in part reflects the magnitude of monetary disturbances during the period. ${ }^{17}$

Table 8.4 shows updated annual statistics on the real exchange rate between the United States and Great Britain. During the floating rate period 197387 , though there is no significant time trend, there is a large standard error of 15.6 percent. The serial correlation in the deviations from PPP is estimated at .687 , with a standard error of .208. (The equation estimated is $\left[e r_{t+1}-\overline{e r}_{t+1}\right)=A R\left[e r_{t}-\overline{e r}\right] \varepsilon_{t+1}$, where $e r$ is the real exchange rate, $\overline{e r}$ is the long-run equilibrium level, alternatively estimated as the sample mean or a time trend, and $A R$ is the autoregressive coefficient.) This means 
Table 8.4

Purchasing Power Parity between the United States and the United Kingdom

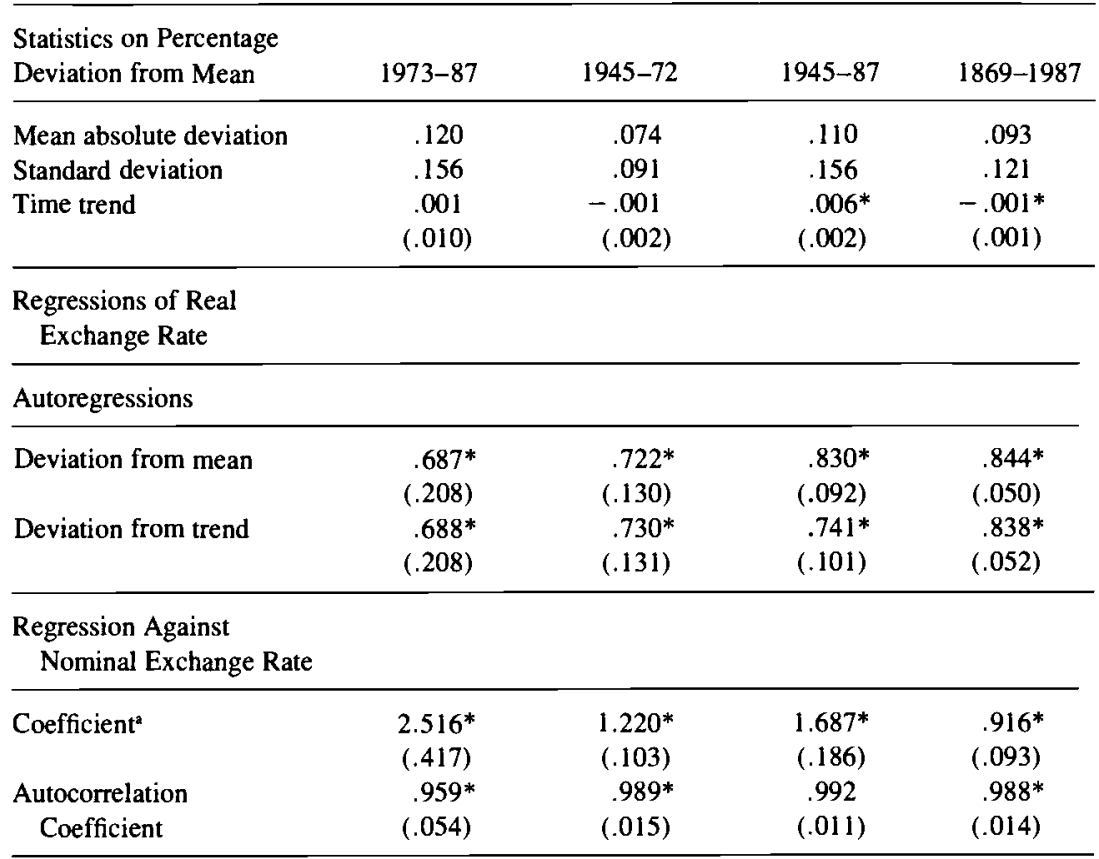

Note: Standard errors are reported in parentheses.

${ }^{2}$ With constant term and correction for autocorrelation.

*Significant at the 95 percent level.

that the estimated speed of adjustment to PPP is .313 per year, and that one can easily reject the hypothesis of instantaneous adjustment.

From the ashes of absolute PPP, a phoenix has risen. In response to findings such as those reported here, some authors have swung from one extreme, the proposition that the tendency of the real exchange rate to return to a constant is complete and instantaneous, to the opposite extreme that there is no such tendency at all. The hypothesis that the real exchange rate follows a random walk is just as good as the hypothesis of absolute PPP for implying ex ante relative PPP. But there is even less of an a priori case why PPP should hold in rate-of-change form than in the level form.

Even though ex ante relative PPP has little basis in theory, it does appear to have some empirical support. Typically, the estimated speeds of adjustment during the floating rate period, .31 in table 8.4 (1973-87), while not so low as to be implausible as point estimates, are nevertheless so low that one statistically cannot reject the hypothesis that they are zero. In other words one cannot reject the random walk hypothesis that the autoregression coefficient is 1.0 . 
A 95 percent confidence interval on the autoregressive coefficient covers the range $0.27-1.10$. If the null hypothesis is an autoregressive coefficient of 1.0 , one cannot legitimately use the standard $t$-test derived from a regression where the right-hand-side variable is the level of the real exchange rate, because under the null hypothesis the variance is infinite. (This does not invalidate the $t$-test just reported of the null hypothesis that the tendency to return to PPP was 100 percent, that is, $A R=0$ ). There are a number of ways of dealing with this nonstationarity problem. Here one simply applies the corrected Dickey-Fuller 95 percent significance level, 3.00. The .31 estimate for the floating-rate period is insignificantly different from zero.

This failure to reject a random walk in the real exchange rate is the same result found by Roll (1979), Frenkel (1981, 699), Adler and Lehman (1983), Darby (1981), Mishkin (1984a, 1351-53) and Pigott and Sweeney (1985). Most of these studies used monthly data. On the one hand, the greater abundance of data reduces the standard error of the estimate but, on the other hand, one is no longer testing whether $A R=.69$ is different from 1.0 , but rather whether $.97\left(=A R^{1 / 12}\right)$ is different from 1.0 , so that it may not be much easier to reject. Another problem is that one does not know that the nature of the true autoregressive process is truly first order on a monthly (or continuous-time) basis. In any case, the monthly date in the studies cited were generally not powerful enough to reject the random walk. ${ }^{18}$

A more promising alternative is to choose a longer time sample to get a more powerful estimate. Table 8.4 also reports statistics for the entire postwar period, 1945-87. PPP held better for the Bretton Woods years than it did after 1973 , as measured either by the mean absolute deviation and standard deviation of the real exchange rate or by the ability to reject the hypothesis of zero autocorrelation. But, despite the longer time sample, one is only at the borderline of being able to reject the random walk. The 95 percent confidence interval for $A R$ runs from 0.64 to 1.02 (or 0.52 to 0.96 , when allowing for a trend in the long-run equilibrium), and the $t$-ratio of 1.85 (or 2.56 , when allowing for the trend) falls short of the Dickey-Fuller 95 percent significance level of 2.93 .

The asymptotic standard error of an estimate of $A R$ is approximately the square root of $\left(1-A R^{2}\right) / N$. So if the true speed of adjustment is on the order of 30 percent a year $(A R=.7)$, a simple calculation suggests that we might require at least 49 years of data $\left(2.93^{2}\left[1-.7^{2}\right] /[1-.7]^{2}=48.6\right)$ to be able to reject the null hypothesis of $A R=1$. It is not very surprising that 43 years of data is not enough, much less the 15 years of data used in most studies. ${ }^{19}$ Econometricians consider the asymptotic standard error on which this calculation is based to be a bad approximation in small samples. But the correct power calculation suggests that, if anything, the sample required to reject a random walk would be even larger than $49 .^{20}$

The last column of table 8.4 presents an entire 119 years of U.S.-U.K. data. With this long a time sample, the standard error is reduced considerably. 
The rejection of no serial correlation in the real exchange rate is even stronger than in the shorter time samples. More important, one is finally able to detect a statistically significant tendency for the real exchange rate to regress to PPP, at a rate of 16 percent a year. The confidence interval for $A R$ runs from 0.75 to 0.94 , safely less than unity, and the $t$-ratio of 3.12 exceeds the DickeyFuller significance level of 2.89.21

The last row of the table reports regressions of the real exchange rate against the nominal exchange rate. The coefficient is highly significant for all time samples. The figures suggest that changes in the nominal rate (due, for example, to devaluations under fixed exchange rates or monetary disturbances under floating exchange rates) in the presence of sticky goods prices cause transitory changes in the real exchange rate. Such results specifically rule out the possibility, which has been occasionally suggested in the past, that apparent deviations from PPP might be attributed to (random) measurement errors in the price data.

The motivation for looking at PPP in this section has been to obtain insight into the expected rate of real depreciation, because that is the variable that can give rise to real interest differentials even in the presence of uncovered interest parity. ${ }^{22}$ In rejecting the random walk description of the real exchange rate, one has rejected the claim that the rationally expected rate of real depreciation is zero. ${ }^{23}$ To take an example, in 1983-84, when the dollar had appreciated some 30 percent above its PPP value, survey data show expected future real depreciation of 4.3 percent per year. It is thus not difficult to explain the existence of the U.S. real interest differential, even without appealing to any sort of risk premium. There is little excuse for authors such as Koraczyk (1985, $350)$ and Darby $(1985,420)$ ruling out the possibility of expected real depreciation a priori and thereby concluding that real interest differentials necessarily constitute risk premiums.

If the failure of ex ante relative purchasing power parity could, in itself, explain the failure of real interest parity, then it could also, by itself, explain the failure of saving and investment to be uncorrelated. In the recent U.S. context, a fall in national saving could cause an increase in the real interest differential and therefore a fall in investment, even if financial markets are perfectly integrated and even if the fall in saving is truly exogenous, provided the real interest differential is associated with expected real depreciation of the dollar.

Demonstrating that the failure of ex ante relative purchasing power parity is capable of producing a correlation between saving and investment is, of course, not the same thing as asserting that this in fact is the explanation for the observed correlation. There are plenty of other competing explanations that have been proposed. But some support for the idea that the existence of expected real depreciation is key to the observed correlation comes from Cardia (1988). She simulates saving and investment rates in a sequence of models featuring shocks to fiscal spending, money growth, and productivity, in order 
to see which models are capable, for empirically-relevant magnitudes of the parameters, of producing saving-investment correlations as high as those observed. To get at some of the explanations that have been most prominently proposed, she constructs models both with and without PPP, both with and without endogenous response of fiscal policy to current account imbalances, and both with and without the small-country assumption. The finding is that the model that allows for deviations from PPP is able to explain savinginvestment correlations as high as one, while the various models that impose PPP are generally not able to do so. ${ }^{24}$

Further empirical support for the idea that the Feldstein-Horioka results may in fact be due to imperfect integration of goods markets, rather than imperfect integration of financial markets, is provided by a test by Bayoumi and Rose (1989). They compute the correlation of saving and investment across regions within the United Kingdom, reasoning that these regions-unlike nations - are highly integrated with respect to their goods markets, and find no positive correlation.

\subsection{A Decomposition of Real Interest Differentials for 25 Countries}

Because there are so many competing definitions of the degree of international capital mobility, it would be worth knowing if the sort of countries that register high by one criterion are also the sort that register high by the others. In this section we look at rates of return in the 1980s across a sample of 25 countries. We begin with the broadest measure of barriers to international capital mobility, the differential in real interest rates, defined as:

$$
r-r^{*}=\left(i-\Delta p^{e}\right)-\left(i^{*}-\Delta p^{e *}\right) .
$$

Subsequently we will decompose the real interest differential into a component due to "political" or country factors and a component due to currency factors:

$$
r-r^{*}=\left(i-i^{*}-f d\right)-\left(f d-\Delta p^{e}+\Delta p^{e *}\right),
$$

where $i$ is the domestic nominal interest rate, $i^{*}$ is the foreign nominal interest rate, and $f d$ is the forward discount on the domestic currency. The first term $\left(i-i^{*}-f d\right)$ is the covered interest differential. We call it the political or country premium because it captures all barriers to integration of financial markets across national boundaries: transactions costs, information costs, capital controls, tax laws that discriminate by country of residence, default risk, and risk of future capital controls. The second term could be described as the real forward discount. We call it the currency premium because it captures differences in assets according to the currency in which they are denominated, rather than in terms of the political jurisdiction in which they are issued. As we will see, the currency premium can in turn be decomposed into two factors, the exchange risk premium and expected real depreciation. 
The decomposition of the real interest differential would not be possible without the use of data on forward exchange rates. Many previous studies have used forward rate data to test covered interest parity, but only for a few countries. The present study uses forward rate data for panel of 25 countries, which so far as I know is the largest set ever examined. The set of 25 includes countries both large and small, industrialized and developing, Atlantic and Pacific. The forward rate data for most of the countries come from Barclay's Bank in London, via Data Resources, Inc. ${ }^{25}$

\subsubsection{Real Interest Differentials}

Table 8.5 reports statistics on three-month real interest differentials for the 25 countries, in each case expressed as the local interest rate measured relative to the Eurodollar interest rate. For local interest rates we use the interbank market rate or, where no market rate exists, the most flexibly determined interest rate available. ${ }^{26}$ We use, to begin with, the realized inflation rates during the ex post three-month period. Column 2 of table 8.5 reports the mean real interest differential during the sample period, September 1982 to January 1988. (In this and subsequent tables, because the ex post data run three months behind the ex ante expectations, they go up to April 1988.) The numbers are negative for a majority of countries, averaging -1.74 across all 25 , which reflects the high level of real dollar interest rates during this period.

The countries are classified into five groups chosen on a priori grounds. The group with real interest rates the farthest below the world rate is Bahrain, Greece, Mexico, Portugal, and South Africa. These five (very diverse) countries bear the burden of representing a wide class of LDCs in our sample. Altogether there are eight countries classified as LDCs that happen to have forward rate data available and thereby appear in our sample; three of these are East Asian countries that are thought to have open financial markets in the 1980s (Hong Kong, Singapore, and Malaysia) and so are here classified separately.

One might object that the large negative real interest differentials in the group of five reflect administered local interest rates that are kept artificially low by "financial repression." But countries cannot maintain artificially low interest rates without barriers to capital outflow. These statistics reflect a low degree of capital mobility precisely as we want them to. In this respect our group of five is typical of LDCs. A number of studies, including much larger LDC samples than available here, have shown the extremes to which real interest rates can go, particularly some very negative levels in the 1970s.

As with the other measures of interest rate differentials that we will be considering below, the mean is not always the most useful statistic. A small mean over a particular sample period may hide fluctuations in both directions. Even if a mean is statistically significant, ${ }^{27}$ it is useful to know in addition the variability of the differential. The standard deviation is reported in table 8.5, column 4 . We also report the root mean squared error in column 5. (This would 
Table 8.5

Real Interest Differentials (local minus Eurodollar; three-month rates): Interest Differential Less Realized Inflation Differential, September 1982 to January 1988

\begin{tabular}{|c|c|c|c|c|c|c|}
\hline & $\begin{array}{c}\text { Number of } \\
\text { Observations } \\
\text { (1) }\end{array}$ & $\begin{array}{l}\text { Mean } \\
(2)\end{array}$ & $\begin{array}{c}\text { Standard } \\
\text { Error of } \\
\text { Mean } \\
\text { (3) }\end{array}$ & $\begin{array}{c}\text { Series } \\
\text { Standard } \\
\text { Deviation } \\
\text { (4) }\end{array}$ & $\begin{array}{c}\text { Root Mean } \\
\text { Squared } \\
\text { Error } \\
(5)\end{array}$ & $\begin{array}{c}95 \\
\text { Percent } \\
\text { Band } \\
(6)\end{array}$ \\
\hline \multicolumn{7}{|c|}{$\begin{array}{l}\text { Open Atlantic } \\
\text { developed countries: }\end{array}$} \\
\hline Canada & 63 & .09 & .38 & 2.09 & 2.09 & 3.96 \\
\hline Germany & 63 & -1.29 & .65 & 2.77 & 3.06 & 5.95 \\
\hline Netherlands & 62 & -.71 & .86 & 3.91 & 3.97 & 7.63 \\
\hline Switzerland & 62 & -2.72 & .81 & 3.39 & 4.36 & 8.43 \\
\hline United Kingdom & 63 & .46 & .79 & 3.45 & 3.48 & 5.69 \\
\hline Group & 313 & -.83 & .66 & 3.16 & 3.46 & \\
\hline \multicolumn{7}{|l|}{ Liberalizing Pacific: } \\
\hline Hong Kong & 62 & -2.89 & .94 & 4.80 & 5.62 & 11.61 \\
\hline Malaysia & 62 & .83 & 1.00 & 4.61 & 4.68 & 8.19 \\
\hline Singapore & 61 & .08 & .68 & 3.33 & 3.34 & 6.71 \\
\hline Group & 185 & -.67 & .82 & 4.28 & 4.62 & \\
\hline \multicolumn{7}{|c|}{$\begin{array}{l}\text { Closed less-developed } \\
\text { countries: }\end{array}$} \\
\hline Bahrain & 60 & 2.19 & 1.46 & 7.10 & 7.44 & 12.93 \\
\hline Greece & 56 & -9.22 & 1.91 & 9.36 & 13.19 & 21.77 \\
\hline Mexico & 62 & -20.28 & 9.43 & 21.19 & 29.45 & 52.13 \\
\hline Portugal & 61 & -3.90 & 2.97 & 11.28 & 11.95 & 23.62 \\
\hline South Africa & 61 & -4.84 & 1.17 & 4.85 & 6.88 & 11.16 \\
\hline Group & 300 & -7.25 & 1.30 & 12.16 & 16.06 & \\
\hline \multicolumn{7}{|c|}{$\begin{array}{l}\text { Closed European } \\
\text { developed countries: }\end{array}$} \\
\hline Austria & 64 & -2.20 & .83 & 3.84 & 4.43 & 7.32 \\
\hline Belgium & 63 & .53 & .68 & 2.90 & 2.95 & 4.99 \\
\hline Denmark & 61 & -3.42 & .90 & 4.34 & 5.54 & 9.64 \\
\hline France & 64 & -.48 & .72 & 2.94 & 2.98 & 5.54 \\
\hline Ireland & 61 & 1.53 & 1.03 & 3.95 & 4.24 & 7.13 \\
\hline Italy & 61 & 1.01 & .86 & 3.62 & 3.76 & 5.83 \\
\hline Norway & 50 & -.64 & .84 & 3.23 & 3.29 & 6.83 \\
\hline Spain & 63 & .53 & 1.44 & 5.92 & 5.95 & 11.90 \\
\hline Sweden & 63 & -.21 & 1.07 & 4.52 & 4.53 & 8.28 \\
\hline Group & 550 & -.37 & .81 & 4.00 & 4.29 & \\
\hline \multicolumn{7}{|c|}{$\begin{array}{l}\text { Liberalizing Pacific } \\
\text { developed countries: }\end{array}$} \\
\hline Australia & 60 & 1.16 & .90 & 3.69 & 3.87 & 7.43 \\
\hline Japan & 63 & -.58 & .62 & 3.41 & 3.46 & 6.03 \\
\hline New Zealand & 60 & 1.04 & 1.83 & 7.15 & 7.23 & 11.36 \\
\hline Group & 183 & .52 & .73 & 5.00 & 5.09 & \\
\hline All countries & 1,531 & -1.74 & & 6.47 & 8.07 & \\
\hline
\end{tabular}


be a superior measure of how closely the rates are tied together if, for example, we are worried about the possibility of a large differential that is fairly constant over time because of government administration of interest rates.) Finally, we report in column 6 how big a band would be needed to encompass 95 percent of the deviations from real interest parity.

Country-group comparisons of the measures of real interest differential variability in some respects suit a priori expectations: the five closed LDCs constitute the group with the highest variability, and the five open Atlantic countries the group with the lowest. ${ }^{28}$ But there are some results that are anomalous if the real interest differential is taken as a measure of financial market integration. France, for example, had stringent capital controls in place during our sample period (at least until the latter part of the period) and yet appears to have a higher degree of capital mobility by the criterion of real interest differential variability than Japan, which announced liberalization of its capital controls before our sample period (1979-80). One might conceivably argue that the Japanese liberalization must not have been genuine. But the French real interest differential is smaller and less variable even than those of the Netherlands and Switzerland, major countries that are known to be virtually free of capital controls. Only Canada shows a smaller and less variable real interest differential than France.

Because the realized inflation rates could not have been precisely known a priori, it is necessary to project them onto contemporaneously known variables. Three such variables were used: the forward discount, nominal interest differential, and lagged inflation differential. (The results are reported in NBER Working Paper no. 2856, but are omitted here to save space.) In a majority of cases, a statistically significant amount of the variation in the real interest differential turned out to be forecastable. ${ }^{29}$ The standard deviation of the projected differential gives us our final measure of variability. The results for the ex ante real interest differential are mostly similar to those for the ex post. France, for example, still shows a lower degree of variability than the Netherlands.

\subsubsection{Covered Interest Differentials: The Country Premium}

We now use the Barclay's forward rate data to decompose the real interest differential into one part due to country factors and another due to currency factors, as in equation (5). The first component, the covered interest differential, encompasses all factors related to the political jurisdiction in which the asset is issued. Its size and variability measures barriers to international capital mobility most narrowly and properly defined.

Column 2 of table 8.6 reports the mean of the covered interest differential for each of our 25 countries. A good rule of thumb, when the absolute magnitude of the mean or the variability of the differential indicates the existence of significant barriers, is as follows: a negative differential vis-à-vis the Eurocurrency market indicates that, to the extent that barriers exist, they are capital 
Table 8.6

"Country Premia" or Covered Interest Differentials (local minus

Eurodollar; three-months rates): Interest Differential Less Forward

Discount, September 1982 to April 1988

\begin{tabular}{|c|c|c|c|c|c|c|}
\hline & $\begin{array}{c}\text { Number of } \\
\text { Observations } \\
\text { (1) }\end{array}$ & $\begin{array}{l}\text { Mean } \\
\text { (2) }\end{array}$ & $\begin{array}{c}\text { Standard } \\
\text { Error of } \\
\text { Mean } \\
\text { (3) }\end{array}$ & $\begin{array}{c}\text { Series } \\
\text { Standard } \\
\text { Deviation } \\
\text { (4) }\end{array}$ & $\begin{array}{c}\text { Root Mean } \\
\text { Squared } \\
\text { Error } \\
\text { (5) }\end{array}$ & $\begin{array}{c}95 \\
\text { Percent } \\
\text { Band } \\
(6)\end{array}$ \\
\hline \multicolumn{7}{|c|}{$\begin{array}{l}\text { Open Atlantic } \\
\text { developed countries: }\end{array}$} \\
\hline Canada & 68 & -.10 & .03 & .21 & .24 & .44 \\
\hline Germany & 68 & .35 & .03 & .24 & .42 & .75 \\
\hline Netherlands & 68 & .21 & .02 & .13 & .25 & .45 \\
\hline Switzerland & 68 & .42 & .03 & .23 & .48 & .79 \\
\hline United Kingdom & 68 & -.14 & .02 & .20 & .25 & .41 \\
\hline Group & 340 & .14 & .01 & .21 & .34 & \\
\hline \multicolumn{7}{|l|}{ Liberalizing Pacific: } \\
\hline Hong Kong & 68 & .13 & .03 & .28 & .31 & .60 \\
\hline Malaysia & 63 & -1.46 & .16 & 1.28 & 1.95 & 3.73 \\
\hline Singapore & 64 & -.30 & .04 & .31 & .43 & .73 \\
\hline Group & 195 & -.52 & .05 & .76 & 1.14 & \\
\hline \multicolumn{7}{|c|}{$\begin{array}{l}\text { Closed less-developed } \\
\text { countries: }\end{array}$} \\
\hline Bahrain & 64 & -2.15 & .13 & 1.06 & 2.41 & 4.17 \\
\hline Greece & 58 & -9.39 & .80 & 6.08 & 11.26 & 20.39 \\
\hline Mexico & 43 & -16.47 & 1.83 & 12.01 & 20.54 & 28.86 \\
\hline Portugal & 61 & -7.93 & 1.23 & 9.59 & 12.49 & 27.83 \\
\hline South Africa & 67 & -1.07 & 1.17 & 9.55 & 9.61 & 2.68 \\
\hline Group & 293 & -6.64 & .48 & 8.23 & 11.82 & \\
\hline \multicolumn{7}{|c|}{$\begin{array}{l}\text { Closed European } \\
\text { developed countires: }\end{array}$} \\
\hline Austria & 65 & .13 & .05 & .39 & .41 & .39 \\
\hline Belgium & 68 & .12 & .03 & .26 & .29 & .59 \\
\hline Denmark & 68 & -3.53 & .19 & 1.57 & 3.89 & 6.63 \\
\hline France & 68 & -1.74 & .32 & 2.68 & 3.20 & 7.18 \\
\hline Ireland & 66 & -.79 & .51 & 4.17 & 4.24 & 7.80 \\
\hline Italy & 68 & -.40 & .23 & 1.92 & 1.96 & 4.11 \\
\hline Norway & 50 & -1.03 & .11 & .76 & 1.29 & 2.10 \\
\hline Spain & 67 & -2.40 & .45 & 3.66 & 4.39 & 7.95 \\
\hline Sweden & 68 & -.23 & .06 & .45 & .51 & .81 \\
\hline Group & 588 & -1.10 & .09 & 2.25 & 2.77 & \\
\hline \multicolumn{7}{|c|}{$\begin{array}{l}\text { Liberalizing Pacific } \\
\text { developed countries: }\end{array}$} \\
\hline Australia & 68 & -.75 & .23 & 1.94 & 2.08 & 2.59 \\
\hline Japan & 68 & .09 & .03 & .21 & .23 & .43 \\
\hline New Zealand & 68 & -1.63 & .29 & 2.42 & 2.92 & 5.24 \\
\hline Group & 204 & -.76 & .12 & 1.78 & 2.06 & \\
\hline All countries & 1,620 & -1.73 & .09 & 3.81 & 5.36 & \\
\hline
\end{tabular}


controls or transactions costs currently operating to discourage capital from flowing out of the country. Investors would not settle for a lower return domestically if they were free to earn abroad the higher return covered to eliminate exchange risk. This is the case for all the LDCs in the sample, with the exception of Hong Kong, and for all of the traditionally "closed" European countries, with the exceptions of Austria and Belgium (which should by now probably be classified with the "open" countries). The negative differential that existed for the United Kingdom before Margaret Thatcher removed capital controls in 1979 is now extremely small. ${ }^{30}$ Similarly, Canada's differential is effectively zero. ${ }^{31}$

Column 6 of table 8.6, the size of the band wide enough to encompass 95 percent of deviations from international covered interest parity, can be compared with the approach of Frenkel and Levich (1977). They tested a larger band meant to represent transactions costs between pound and dollar securities. They found, for the case of the United Kingdom, that a smaller percentage of deviations (87.6-89.7 percent; Frenkel and Levich 1977, 1217) fell within the band. This confirms that capital mobility has increased since the 1970s.

Germany and several other neighboring European countries (Switzerland, the Netherlands, Austria, and Belgium) show higher interest rates locally than offshore, which suggests some barriers discouraging capital inflow: investors would not settle for a lower mark return in the Euromarket if they were free to get the higher return in Germany. But the magnitude is quite small, as it has been observed to be ever since Germany removed most of its controls on capital inflow in 1974 (Dooley and Isard 1980; and Giavazzi and Pagano 1985, 27).

Japan has a covered differential that by all measures is smaller and less variable than those of Switzerland and Germany, let alone France and most of the other countries. This might come as a surprise to those accustomed to thinking of Japanese financial markets in terms of the large barriers to capital inflow that were in place in the 1970s. The liberalization of Japanese markets, which has been documented elsewhere, continued during our sample period..$^{32}$ Australia and New Zealand, while lagging well behind Japan, also show signs of liberalization during the course of our sample period..$^{33}$

The covered interest differential for France is much larger and more variable than that for the other major industrialized countries known to be free of capital controls. This is the reverse of the finding from the criterion of real interest differentials in table 8.5. It supports the value of the criterion of covered interest differentials as the proper test of financial market integration. The differential, with its negative sign signifying controls on French capital outflows, has been previously studied, especially its tendency to shoot up shortly before devaluations of the franc. ${ }^{34}$ Our data indicate that the last major occurrence of this phenomenon was February 1986; since then the differential has been close to zero. 
Similarly, the same phenomenon for Italy, which has also been previously studied (e.g., Giavazzi and Pagano 1985), appears to have ended after the February 1986 realignment. France and Italy dismantled their capital controls quickly enough to meet a 1990 deadline for liberalization recently set by the EEC Twelve. ${ }^{35}$ Of four countries that required a later deadline, Spain and Portugal have by our measures already been liberalizing (plots show that the magnitude of the covered interest differential fell sharply in 1987 for these two countries), but Greece and Ireland have not. Sweden is one non-EEC European country that appears to have moved toward liberalization during our sample period, while Norway does not. All of these European countries show up with negative mean differentials, which implies that the remaining controls act to discourage capital outflow rather than inflow. For the EEC countries, this finding supports records of the European Commission, which reports more freedom for short-term inflows than short-term outflows. ${ }^{36}$

Registering impressively open financial markets are our three East Asian LDCs (which, especially in the case of Singapore, have rapidly outgrown the appellation "less developed"). Hong Kong and Singapore show smaller covered differentials even than some open European countries like Germany. Malaysia's differential has been considerably higher, particularly in 1986, but still compares favorably with some European countries.

Not surprisingly, our remaining LDCs (Mexico, Greece, Portugal, Bahrain, and South Africa) show by far the largest and most variable covered interest differentials. ${ }^{37}$ Again, the results are precisely what one would expect if covered interest differentials are the proper criterion for capital mobility, but the reverse of what the saving-investment criterion shows.

Why does the covered differential criterion give such different answers from the saving-investment criterion, which shows a high degree of saving retention among industrialized countries? Feldstein and Horioka $(1980,315)$ argue that financial markets are less well integrated at longer-term maturities, as compared to the three-month maturities used in tests of covered interest parity such as those reported above: "It is clear from the yields on short-term securities in the Eurocurrency market and the forward prices of those currencies that liquid financial capital moves very rapidly to arbitrage such short-term differentials. . . . There are however reasons to be sceptical about the extent of such long-term arbitrage."

Studies of international interest parity have been restricted by a lack of forward exchange rates at horizons going out much further than one year. ${ }^{38}$ But even without the use of forward rate data, there are ways of getting around the problem of exchange risk. Data on currency swap rates can be used in place of forward exchange rates to test the long-term version of interest rate parity. Popper (1990) finds that the swap-covered return differential on five-year U.S. government bonds versus Japanese bonds averaged only 1.7 basis points from October 3, 1985 to July 10,1986 , and that the differential on seven-year bonds averaged only 5.3 basis points. The means mask some variation in the 
differential. But a band of 46 basis points is large enough to encompass 95 percent of the observations for the five-year bonds. The band is 34 basis points for the seven-year bonds. The means on five-year bonds for some other major countries are as follows: Canada 15.9, Switzerland 18.7, United Kingdom 51.1 , and Germany 28.4.

The magnitude of these long-term differentials compares favorably with the magnitude of the short-term differentials. The implication is that Feldstein and Horioka are wrong in their conjecture that there is a term-structure wedge separating national capital markets. ${ }^{39}$ The most relevant distinction appears to be, not long-term versus short-term, but rather real versus nominal.

\subsection{3 "Real Forward Discounts": The Currency Premium}

Even for those countries that exhibit no substantial country premium, as reflected in covered interest parity ( $\left.f d-\left[i-i^{*}\right]=0\right)$, there may still be a substantial currency premium that drives real interest differentials $\left(\left[i-\Delta p^{e}\right]-\left[i^{*}-\Delta p^{* *}\right]\right)$ away from zero. If real interest differentials are not arbitraged to zero, then there is in turn no reason to expect savinginvestment correlations to be zero. Table 8.7 reports the statistics for the currency premium, as measured by the "real forward discount":

$$
f d-\left(\Delta p^{e}-\Delta p^{e *}\right) \text {. }
$$

Germany, Switzerland, the Netherlands, Austria, and Japan, for example, all have substantial real forward discounts (or-more precisely-real forward premia), which constitute approximately the entirety of their real interest differentials. These are countries with currencies that have experienced a lot of exchange rate variability, both nominal and real, vis-à-vis the dollar since 1973 , and especially since 1980 . As a consequence, some combination of exchange risk premiums and expected real depreciation-factors pertaining to the currency, not to the political jurisdiction-produces the gap in real interest rates. For these five financially open industrialized countries, and for Hong Kong as well, the currency factors produce a negative real interest differential, while the covered interest differential (though small) is positive: the small regulations or frictions that remain in these countries are, if anything, working to resist capital inflow (at least at the short end of the maturity spectrum), not outflow as one would mistakenly conclude from the real interest differential criterion. The other countries all have highly variable currency premiums as well. Indeed the real forward discount (currency premium) is more variable than the covered interest differential (country premium) for all but three of our 25 countries (Greece, Mexico, and France). The last rows of tables 8.6 and 8.7 show that the average variability across all countries is higher for the currency premium than for the country premium.

We can project the real forward discount on the same three variables as we did for the real interest differential (the forward discount, nominal interest differential, and lagged inflation differential) to get an ex ante measure. ${ }^{40}$ Its 
Table 8.7

"Currency Premia" or Real Forward Discounts: Forward Discount Less Realized Inflation Differential, September 1982 to January 1988

\begin{tabular}{|c|c|c|c|c|c|c|}
\hline & $\begin{array}{l}\text { Number of } \\
\text { Observations } \\
\text { (1) }\end{array}$ & $\begin{array}{c}\text { Mean } \\
(2)\end{array}$ & $\begin{array}{l}\text { Standard } \\
\text { Error of } \\
\text { Mean } \\
\text { (3) }\end{array}$ & $\begin{array}{c}\text { Series } \\
\text { Standard } \\
\text { Deviation } \\
\text { (4) }\end{array}$ & $\begin{array}{c}\text { Root Mean } \\
\text { Squared } \\
\text { Error } \\
(5)\end{array}$ & $\begin{array}{c}95 \\
\text { Percent } \\
\text { Band } \\
(6)\end{array}$ \\
\hline \multicolumn{7}{|c|}{$\begin{array}{l}\text { Open Atlantic } \\
\text { developed countries: }\end{array}$} \\
\hline Canada & 63 & .18 & .38 & 2.08 & 2.09 & 4.02 \\
\hline Germany & 63 & -1.66 & .69 & 2.89 & 3.34 & 6.57 \\
\hline Netherlands & 62 & -.92 & .88 & 3.98 & 4.09 & 7.52 \\
\hline Switzerland & 62 & -3.15 & .84 & 3.49 & 4.72 & 8.79 \\
\hline United Kingdom & 63 & .61 & .83 & 3.56 & 3.61 & 5.97 \\
\hline Group & 313 & -.98 & .69 & 3.24 & 3.65 & \\
\hline \multicolumn{7}{|l|}{ Liberalizing Pacific: } \\
\hline Hong Kong & 62 & -2.99 & .93 & 4.79 & 5.66 & 11.76 \\
\hline Malaysia & 62 & 2.29 & 1.14 & 5.06 & 5.56 & 10.17 \\
\hline Singapore & 62 & .40 & .67 & .32 & 3.35 & 6.86 \\
\hline Group & 186 & -.10 & .82 & 4.43 & 4.95 & \\
\hline \multicolumn{7}{|c|}{$\begin{array}{l}\text { Closed less-developed } \\
\text { countries: }\end{array}$} \\
\hline Bahrain & 60 & 4.37 & 1.52 & 7.27 & 8.51 & 16.18 \\
\hline Greece & 60 & .83 & 1.67 & 9.98 & 10.01 & 18.77 \\
\hline Mexico & 43 & .03 & 3.58 & 15.23 & 15.23 & 22.08 \\
\hline Portugal & 59 & 4.94 & 2.13 & 11.73 & 12.74 & 21.56 \\
\hline South Africa & 62 & -3.82 & 1.81 & 11.36 & 11.99 & 14.75 \\
\hline Group & 284 & 1.29 & 1.37 & 11.05 & 11.60 & \\
\hline \multicolumn{7}{|c|}{$\begin{array}{l}\text { Closed European } \\
\text { developed countries: }\end{array}$} \\
\hline Austria & 62 & -2.25 & .88 & 3.94 & 4.55 & 7.68 \\
\hline Belgium & 63 & .42 & .69 & 2.95 & 2.98 & 5.05 \\
\hline Denmark & 61 & .14 & 1.01 & 4.63 & 4.63 & 7.13 \\
\hline France & 64 & 1.35 & .54 & 2.50 & 2.85 & 4.82 \\
\hline Ireland & 59 & 2.14 & 1.40 & 6.41 & 6.76 & 13.85 \\
\hline Italy & 61 & 1.42 & .72 & 3.15 & 3.46 & 5.52 \\
\hline Norway & 64 & 1.07 & .75 & 3.25 & 3.43 & 5.91 \\
\hline Spain & 63 & 3.12 & 1.26 & 5.53 & 6.36 & 11.08 \\
\hline Sweden & 63 & .04 & 1.07 & 4.57 & 4.57 & 8.29 \\
\hline Group & 560 & .83 & .67 & 4.23 & 4.54 & \\
\hline \multicolumn{7}{|c|}{$\begin{array}{l}\text { Liberalizing Pacific } \\
\text { developed countries: }\end{array}$} \\
\hline Australia & 60 & 1.97 & .88 & 4.06 & 4.52 & 7.85 \\
\hline Japan & 63 & -.69 & .64 & 3.48 & 3.55 & 6.32 \\
\hline New Zealand & 60 & 2.82 & 1.98 & 7.96 & 8.46 & 14.11 \\
\hline Group & 183 & 1.33 & .79 & 5.48 & 5.84 & \\
\hline All countries & 1,526 & .49 & & 6.11 & 6.50 & \\
\hline
\end{tabular}


standard deviation now shows six countries for whom the currency premium is less variable than the country premium (Greece, Mexico, Portugal, France, Italy, and Spain). But the currency premium remains the major obstacle to real interest parity for most countries.

\subsubsection{Further Decomposition into Exchange Risk Premium and Expected Real Depreciation}

Our decomposition so far has lumped two terms, the exchange risk premium and expected real depreciation, together into the currency premium:

$$
f d-\Delta p^{e}+\Delta p^{e *}=\left(f d-\Delta s^{e}\right)+\left(\Delta s^{e}-\Delta p^{e}+\Delta p^{e *}\right) .
$$

In this section we attempt to complete the decomposition by separating these two terms. To do so requires a measure or model of expected depreciation. The usual approach is to use the ex post changes in the spot rate $(\Delta s)$ as a measure of ex ante expectations $\left(\Delta s^{e}\right)$, and to argue that under rational expectations the expectational error $\left(e \equiv \Delta s-\Delta s^{e}\right)$ should be random (uncorrelated with information currently available at time $t$ ).

Column 2 of table 8.8 reports the mean value of $(f d-\Delta s)$ for each of our countries. Most of the means are positive, showing that the weak-dollar period (1985-88) dominates over the strong-dollar period (1982-1985). ${ }^{41}$ But only three currencies have mean risk premiums, of either sign, that are statistically significant. ${ }^{42}$ Furthermore, in a majority of cases $(16 / 25)$, the sign of the mean return differential is the opposite of the sign of the mean real interest differential during the same period (table 8.5, col. 2). So this measure of the exchange risk premium does not explain any positive part of the real interest differential.

The measures of variability of $(f d-\Delta s)$ show up very large in columns 4 , 5 , and 6 . These are measures of the variability of ex post return differentials, not ex ante. They tell us little about the variability of the exchange risk premium. But the high variability of the exchange rate does tell us two things. First, it provides an obvious explanation-low power-why the first moments might not be statistically significant. On the other hand, the existence of substantial uncertainty regarding the future spot rate suggests, via the theory of optimal portfolio diversification, that a nonzero exchange risk premium must exist, to reward risk-averse investors for holding currencies that are perceived as risky or that are in oversupply.

To estimate the ex ante exchange risk premium, we can project $(f d-\Delta s)$ onto our same three variables: the forward discount, interest differential, and inflation differential ${ }^{43}$ The regression is statistically significant for a majority of currencies, as many others have found. ${ }^{44}$ The standard deviation shows the most variable exchange risk premiums belong to Mexico and New Zealand, but the United Kingdom, Netherlands, Austria, Germany, and Switzerland follow close behind.

In table 8.9 we report the statistics for the other component of the currency 
Table 8.8

Return to Forward Exchange Speculation: Forward Discount Less Realized Exchange Depreciation, September 1982 to January 1988

\begin{tabular}{|c|c|c|c|c|c|c|}
\hline & $\begin{array}{l}\text { Number of } \\
\text { Observations } \\
\text { (1) }\end{array}$ & $\begin{array}{l}\text { Mean } \\
(2)\end{array}$ & $\begin{array}{l}\text { Standard } \\
\text { Error of } \\
\text { Mean } \\
\text { (3) }\end{array}$ & $\begin{array}{c}\text { Series } \\
\text { Standard } \\
\text { Deviation } \\
(4)\end{array}$ & $\begin{array}{l}\text { Root Mean } \\
\text { Squared } \\
\text { Error } \\
\text { (5) }\end{array}$ & $\begin{array}{c}95 \\
\text { Percent } \\
\text { Band } \\
(6)\end{array}$ \\
\hline \multicolumn{7}{|c|}{$\begin{array}{l}\text { Open Atlantic } \\
\text { developed countries: }\end{array}$} \\
\hline Canada & 65 & 1.04 & 2.03 & 9.15 & 9.21 & 16.95 \\
\hline Germany & 65 & 4.11 & 5.92 & 25.85 & 26.18 & 44.23 \\
\hline Netherlands & 65 & 4.35 & 6.09 & 26.32 & 26.68 & 44.91 \\
\hline Switzerland & 65 & 3.98 & 6.22 & 27.74 & 28.02 & 46.77 \\
\hline United Kingdom & 65 & 3.77 & 6.21 & 27.72 & 27.98 & 42.95 \\
\hline Group & 325 & 3.45 & 5.36 & 24.27 & 24.55 & \\
\hline \multicolumn{7}{|l|}{ Liberalizing Pacific: } \\
\hline Hong Kong & 65 & -3.78 & 2.22 & 10.76 & 11.41 & 24.43 \\
\hline Malaysia & 65 & -.74 & 2.31 & 10.31 & 10.34 & 18.92 \\
\hline Singapore & 65 & -.35 & 2.01 & 9.64 & 9.65 & 18.07 \\
\hline Group & 195 & -1.62 & 1.71 & 10.19 & 10.44 & \\
\hline \multicolumn{7}{|c|}{$\begin{array}{l}\text { Closed less-developed } \\
\text { countries: }\end{array}$} \\
\hline Greece & 65 & 3.64 & 5.32 & 25.84 & 25.10 & 46.22 \\
\hline Mexico & 43 & 6.04 & 12.29 & 50.74 & 51.10 & 89.44 \\
\hline Portugal & 61 & 11.27 & 5.07 & 22.53 & 25.23 & 41.80 \\
\hline Saudi Arabia & 65 & -1.49 & 0.52 & 2.82 & 3.19 & 5.55 \\
\hline South Africa & 65 & -4.83 & 9.19 & 42.50 & 42.77 & 83.90 \\
\hline Group & 299 & 2.59 & 3.83 & 31.59 & 32.21 & \\
\hline \multicolumn{7}{|c|}{$\begin{array}{l}\text { Closed European } \\
\text { developed countries: }\end{array}$} \\
\hline Austria & 63 & 5.38 & 6.00 & 26.27 & 26.82 & 46.00 \\
\hline Belgium & 65 & 7.51 & 5.40 & 23.77 & 24.94 & 44.75 \\
\hline Denmark & 65 & 5.50 & 5.51 & 24.27 & 25.42 & 43.91 \\
\hline France & 65 & 7.47 & 5.54 & 24.23 & 25.37 & 42.98 \\
\hline Ireland & 63 & 7.27 & 5.75 & 24.67 & 25.73 & 45.05 \\
\hline Italy & 65 & 8.77 & 5.33 & 23.20 & 24.82 & 40.91 \\
\hline Norway & 65 & 7.20 & 4.73 & 21.10 & 22.31 & 38.55 \\
\hline Spain & 65 & 8.98 & 5.04 & 22.28 & 24.05 & 45.08 \\
\hline Sweden & 65 & 6.20 & 4.47 & 20.21 & 21.15 & 39.05 \\
\hline Group & 581 & 7.37 & 5.82 & 23.22 & 24.39 & \\
\hline \multicolumn{7}{|c|}{$\begin{array}{l}\text { Liberalizing Pacific } \\
\text { developed countries: }\end{array}$} \\
\hline Australia & 65 & 1.09 & 6.55 & 32.41 & 32.43 & 61.46 \\
\hline Japan & 65 & 10.98 & 5.27 & 25.12 & 27.45 & 53.50 \\
\hline New Zealand & 65 & 8.81 & 8.42 & 36.98 & 38.03 & 73.92 \\
\hline Group & 195 & 6.96 & 5.59 & 31.72 & 32.75 & \\
\hline All countries & 1,595 & 4.53 & & 25.25 & 26.01 & \\
\hline
\end{tabular}


Tahle 8.9

Realized Exchange Depreciation Less Realized Inflation Differential, September 1982 to January 1988

\begin{tabular}{|c|c|c|c|c|c|c|}
\hline & $\begin{array}{c}\text { Number of } \\
\text { Observations } \\
\text { (1) }\end{array}$ & $\begin{array}{l}\text { Mean } \\
(2)\end{array}$ & $\begin{array}{l}\text { Standard } \\
\text { Error of } \\
\text { Mean } \\
\text { (3) }\end{array}$ & $\begin{array}{c}\text { Series } \\
\text { Standard } \\
\text { Deviation } \\
\text { (4) }\end{array}$ & $\begin{array}{l}\text { Root Mean } \\
\text { Squared } \\
\text { Error } \\
(5)\end{array}$ & $\begin{array}{c}95 \\
\text { Percent } \\
\text { Band } \\
(6)\end{array}$ \\
\hline \multicolumn{7}{|c|}{$\begin{array}{l}\text { Open Atlantic } \\
\text { developed countries: }\end{array}$} \\
\hline Canada & 63 & -.27 & 1.81 & 8.45 & 8.46 & 15.17 \\
\hline Germany & 63 & -6.35 & 5.75 & 25.10 & 25.90 & 44.21 \\
\hline Netherlands & 62 & -6.11 & 5.90 & 25.14 & 25.88 & 43.78 \\
\hline Switzerland & 62 & -8.35 & 6.11 & 26.78 & 28.07 & 45.67 \\
\hline United Kingdom & 63 & -2.84 & 6.06 & 27.29 & 27.44 & 47.88 \\
\hline Group & 313 & -4.77 & 5.24 & 23.48 & 24.13 & \\
\hline \multicolumn{7}{|l|}{ Liberalizing Pacific: } \\
\hline Hong Kong & 62 & .62 & 2.23 & 10.61 & 10.63 & 22.57 \\
\hline Malaysia & 62 & 2.44 & 2.46 & 10.60 & 10.88 & 19.74 \\
\hline Singapore & 62 & .63 & 2.39 & 10.86 & 10.88 & 19.23 \\
\hline Group & 186 & 1.23 & 2.11 & 10.63 & 10.74 & \\
\hline \multicolumn{7}{|l|}{$\begin{array}{l}\text { Closed less-developed } \\
\text { countries: }\end{array}$} \\
\hline Bahrain & 60 & 5.92 & 1.62 & 7.94 & 9.94 & 21.24 \\
\hline Greece & 60 & -1.82 & 4.99 & 25.08 & 25.15 & 46.41 \\
\hline Mexico & 62 & -3.32 & 9.31 & 47.96 & 48.96 & 89.57 \\
\hline Portugal & 57 & -8.12 & 4.73 & 22.63 & 24.06 & 46.25 \\
\hline South Africa & 62 & -.27 & 10.74 & 47.16 & 47.16 & 78.62 \\
\hline Group & 301 & -1.46 & 4.27 & 33.93 & 34.26 & \\
\hline \multicolumn{7}{|c|}{$\begin{array}{l}\text { Closed European } \\
\text { developed countires: }\end{array}$} \\
\hline Austria & 64 & -7.30 & 5.64 & 25.16 & 26.21 & 44.92 \\
\hline Belgium & 63 & -7.69 & 5.09 & 22.61 & 23.90 & 44.90 \\
\hline Denmark & 61 & -7.94 & 5.60 & 24.05 & 25.35 & 41.85 \\
\hline France & 64 & -6.26 & 5.39 & 24.87 & 24.87 & 42.24 \\
\hline Ireland & 61 & -5.85 & 5.56 & 24.12 & 24.84 & 43.47 \\
\hline Italy & 61 & -8.01 & 5.44 & 23.24 & 24.60 & 41.38 \\
\hline Norway & 64 & -5.92 & 4.64 & 21.05 & 21.88 & 37.90 \\
\hline Spain & 63 & -6.01 & 5.25 & 22.67 & 23.47 & 39.51 \\
\hline Sweden & 63 & -6.23 & 3.95 & 18.36 & 19.41 & 33.17 \\
\hline Group & 564 & -6.79 & 5.76 & 22.73 & 23.74 & \\
\hline \multicolumn{7}{|l|}{ Liberalizing Pacific } \\
\hline Australia & 60 & 2.38 & 6.78 & 33.00 & 33.09 & 70.90 \\
\hline Japan & 63 & -12.13 & 5.63 & 25.30 & 28.10 & 52.98 \\
\hline New Zealand & 60 & -4.77 & 8.49 & 37.00 & 37.31 & 82.32 \\
\hline Group & 183 & -4.96 & 5.63 & 31.86 & 32.79 & \\
\hline All countries & 1,547 & -4.16 & & 25.61 & 26.28 & \\
\hline
\end{tabular}


premium, expected real depreciation. As noted earlier, given the widely accepted failure of purchasing power parity on levels, there is no theoretical reason to expect it necessarily to hold in terms of expected rates of change, the hypothesis sometimes known as ex ante relative purchasing power parity. Table 8.9 reports the statistics for ex post real depreciation. The means in column 2 are negative, indicating real appreciation of the currency against the dollar, for all European countries and for most others as well. The only five exceptions, countries that experienced real depreciation against the dollar, were our three East Asian developing countries, Australia, and Bahrain. This last was the only one, of either sign, that was statistically significant.

We already know, from the results reported above for the 119 years of U.S.U.K. data, that we cannot expect to reject ex ante relative PPP on just a few years of data: new disturbances to the real exchange rate are so large that one needs a much longer time sample to find evidence of systematic movement. But the signs of the mean real depreciations are usually the same as the signs of the mean real interest differentials in Table 8.5 (20/25), suggesting a high correlation of the real interest differential and expected real depreciation across countries. ${ }^{45}$

To estimate ex ante real depreciation, we project ex post real depreciation, again, on the same three contemporaneous variables. ${ }^{46}$ The standard deviations for the various currencies are quite similar to those for the projected exchange risk premium. ${ }^{47}$ In most cases (18/25) the projected exchange risk premium is slightly more variable than projected real depreciation.

\subsection{Conclusion}

We can sum up with four conclusions.

1. Capital controls and other barriers to the movement of capital across national borders remained for such countries as the United Kingdom and Japan as recently as 1979, and France and Italy as recently as 1986. But a continuing worldwide trend of integration of financial markets in the 1980s had all but eliminated short-term interest differentials for major industrialized countries by 1988 .

2. Only the country premium has been eliminated; this means that only covered interest differentials are small. Real and nominal exchange rate variability remain, and indeed were larger in the 1980s than in the 1970s. ${ }^{48}$ The result is that a currency premium remains, consisting of an exchange risk premium plus expected real currency depreciation. This means that, even with the equalization of covered interest rates, large differentials in real interest rates remain.

3. The United States in the 1980s began to borrow on such a massive scale internationally that the traditional "Feldstein-Horioka" finding of a near-unit correlation between national saving and investment has broken down. The 
process of liberalization in Japan and other major countries was probably one factor behind this massive flow of capital to the United States.

4. In addition to the gaps that distinguish covered interest parity from real interest parity, there is a further gap that separates real interest parity from the proposition that changes in national saving do not crowd out investment because they are readily financed by borrowing from abroad. Bonds are not perfect substitutes for equities, and equities are not perfect substitutes for plant and equipment. Thus at each stage, there are good reasons to think that shortfalls in national saving continue to be capable of crowding out investment, even if to a smaller extent than before 1980 .

\section{Notes}

1. Despite the increased attention to inward foreign direct investment in the United States in recent years, it continues to be a smaller component of the capital inflow than portfolio investment. As of the end of 1987, foreign direct investment accounted for only 17 percent of the total stock of foreign-held assets in the United States.

2. There were relatively large differentials separating U.S. interest rates from the Eurodollar rates; at the long-term end of the spectrum, well-known U.S. corporations could borrow more cheaply in the Euromarket than domestically. These differentials fell steadily toward zero between 1982 and 1986 , probably as the outcome of innovation that occurred in the Euromarkets-partly in response to these differentials-making it easier for U.S. corporations to borrow there. Much of this innovation went under the name of securitization. See Frankel (1988a) for documentation and further references. (It appears that the securitization trend suffered a setback in 1987 and 1988, in part associated with the October 1987 stockmarket crash; it is now said to be slightly more costly for U.S. corporations to issue bonds in the Euromarket than domestically. It remains to be seen whether this reversal of the trend toward perfect integration is serious or lasting.)

3. Even if this relationship does not break down in the future under pressure from fears of international creditors that U.S. indebtedness is becoming excessive.

4. There is a fifth possible-yet more narrowly defined - criterion for the degree of integration of financial markets: the size of transactions costs as measured directly by the bid-ask spread in, for example, the foreign exchange market. Surprisingly, the covered interest differential does not appear to be statistically related to the bid-ask spread (MacArthur 1988).

5. Obstfeld (1986) and Summers (1988) argue that the saving-investment correlation may be due to the common influence of growth rates.

6. Obstfeld $(1986,1989)$ makes the large-country point in a time-series context, where it properly belongs. But even in a time-series regression for a single country such as the United States, one can correct for the large-country problem by expressing saving and investment rates as deviations from the rest-of-world rates of saving and investment, respectively. Under the null hypothesis, an exogenous fall in the U.S. saving rate may drive up the world real interest rate and crowd out investment, but there is no evident reason for the crowding-out to be reflected in U.S. investment to any greater extent than in rest-of-the-world investment. In Frankel (1986, 44-45), I 
found that the close correspondence between U.S. saving and investment for 1970-85 remains, even with this adjustment.

7. Obstfeld (1986a) finds that the coefficient fell after 1973, in time-series correlations for most of his countries, but Obstfeld (1989) finds that it has risen over time (1967-84 vs. 1956-66), with the United States showing the highest correlation of any.

8. In a U.S. time-series context, Frankel (1986) used two instrumental variables: the fraction of the population over 65 years of age and the ratio of military expenditure to GNP. The former is considered a determinant of private saving and the latter of public saving, and both have some claim to exogeneity. In the context of cross-sections of developing and industrialized countries, Dooley, Frankel, and Mathieson (1987) used the dependency ratio and, again, the military expenditure variable.

9. Other studies that reject real interest parity for major industrialized countries include Mishkin (1984a, 1984b), Cumby and Obstfeld (1984), Mark (1985), and Cumby and Mishkin (1986). Glick (1987) examines real interest differentials for six Pacific Basin countries vis-à-vis the United States.

10. The 10-year real interest differential vis-à-vis a weighted average of G-5 countries was about 3 percent in 1984, whether expected inflation is measured by a distributed lag, by OECD forecasts, or by Data Resources, Inc. (DRI) forecasts. In 1980, by contrast, the differential was about -2 percent. Frankel (1986, 35-36).

11. Gross investment was 16.0 percent of GNP in 1980 , which was itself considered a low number (down 0.5 percent from 1971-80).

12. The instrumental variables used are the dependency ratio (the sum of those older than 64 and those younger than 21 , divided by the working-age population in between), which is a determinant of private saving, and military expenditure as a share of GNP, which is a determinant of the federal budget deficit. A data appendix is available for details on these and the other variables.

13. There are two other potential sources of differences from the results in Frankel (1986): the Commerce Department released revised national accounts data for the entire period in 1986, and we now use the dependency ratio as the demographic instrumental variable in place of the ratio of the over- 65 to the over- 20 population. But the years 1985-87 are indeed the source of the fall in the coefficient; when these three years are omitted the coefficient is over 1 (as when the 1980s are omitted in table 8.3).

14. If the 1956-87 sample is split at 1974, when the United States and Germany removed capital controls, rather than at 1979 , there is still a precipitous decline in the cyclically adjusted saving-investment coefficient over time: from .87 (statistically, no difference from 1) to .31 (borderline difference from 0). (See table 3a in the working paper version.) If the 1930-87 sample is split at 1958, when many European countries restored currency convertibility, there is a small increase in the coefficient over time: from .83 (statistically different from 1 ) to 1.14 (no difference from 1). (See table $2 \mathrm{a}$ in the working paper version.) But this is no doubt because the saving and investment rates are not cyclically adjusted for this period (the BEA series is not available back to 1930). Only when expressed on a cyclically adjusted basis is the U.S. national saving rate of 1985-1987 especially low.

15. Feldstein and Bacchetta (in this volume) find a similar drop in the savinginvestment coefficient in the $1980 \mathrm{~s}$, for a cross-section of industrialized countries (though they do not use instrumental variables, and are thus liable to the econometric criticisms that others have raised concerning the endogeneity of national saving).

16. Measuring barriers to integration by differences in rates of return has the problem that a given degree of integration can appear smaller or larger depending on the disturbances to saving (or to other variables) during the sample period in question. For example, the greater degree of variability in the U.S. real interest differential in the 1980 s, as compared to the 1970 s or 1960 s, could be attributed to the greater swings in variables such as the structural budget deficit, rather than to a lower degree of capital 
mobility. (In any case, the degree of variability in covered interest differentials is very low in the 1980s, as we will see below.) All we can say for sure is that if the barriers to integration are essentially zero (the degree of capital mobility is essentially perfect), then differentials in rates of return should be essentially zero.

17. For example, Krugman (1978) found that the standard deviation for the real mark/dollar exchange rate during the German hyperinflation, February 1920 through December 1923, was much larger (20.8 percent) than during the $1970 \mathrm{~s}$, even though the serial correlation was no higher $(.765)$.

18. Cumby and Obstfeld $(1984,146)$ used a $Q$-statistic to test for higher-order serial correlation in monthly real exchange rate changes and found none. However they also found that expected inflation differentials were unrelated to expected exchange rate changes, rejecting the random walk characterization of the real exchange rate. Huizinga (1986) was also able to reject the random walk in some cases.

19. As already noted, an $A R$ coefficient of .7 on a yearly basis corresponds to an $A R$ of .97 on a monthly basis $\left(.97^{12}=.70\right)$. Thus it might take 564 months of data $\left(2.93^{2}\left[1-.97^{2}\right] /[1-.97]^{2}=563.7\right)$ to be able to reject the null hypothesis of $A R=1$. This is 47 years, very little gain in efficiency over the test on yearly data. Summers (1986) demonstrates the low power of random walk tests in the context of stock market prices.

20. DeJong, Nankervis, Savin, and Whiteman (1988, table 2) offer power tables for the Dickey-Fuller test that show that when the true $A R$ parameter is .8 , even a sample size of 100 is sufficient to reject a random walk only about 65 percent of the time.

21. As the sample period covers a number of changes in exchange rate regime, it would be desirable to allow for shifts in the coefficient (and in the variance of the disturbance term). But many of the proponents of a random walk in the real exchange rate claim it as evidence in favor of an "equilibrium" hypothesis, under which fluctuations in the real exchange rate are caused only by real, as opposed to monetary, factors. Under this null hypothesis, changes in regime should not matter for the real exchange rate. Thus our statistical test is a valid rejection of the null hypothesis, even though it lumps together all the 119 years of observations.

22. Sticky goods prices are only one of a number of possible sources of deviations from ex ante relative PPP. Another is the existence of the prices of nontraded goods in the relevant price index. Dornbusch (1983) shows how movement in the relative price of nontraded goods affects the real interest rate, saving, and borrowing from abroad, while Engel and Kletzer (1989) show specifically how such movement can give rise to the Feldstein-Horioka finding. Bovenberg (1989) too shows how imperfect substitutability of goods can give rise to the finding.

23. The rationally expected rate of real depreciation estimated from a specific timeseries process is not necessarily the same as the actual expectation of real depreciation held by investors. Frankel (1986, 58-59) used survey data on expectations of exchange rate changes (collected by the Economist-affiliated Financial Report) and forecasts of price level changes (by DRI) to compute a direct measure of expected real depreciation for the dollar against five currencies. The numbers showed an expectation that the real exchange rate tends to regress back toward PPP at a statistically significant rate of 812 percent a year. (The expected speed of nominal depreciation back toward PPP is estimated more sharply at 12-16 percent a year in Frankel and Froot 1987). For a thorough rejection of the view that investors' expected exchange rate changes are zero, see Froot and Frankel 1989.)

24. Obstfeld (1986a) shows, in a life-cycle model of saving with actual OECD data on the functional distribution of income and on population growth, that the coefficient in an investment regression can be similar to those estimated by Feldstein and Horioka. (Similar claims based on models of intertemporal optimization are made by Ghosh 1988; Roubini 1988; Tesar 1988; and Leiderman and Razin 1989.) But Feldstein and 
Bacchetta (1989) argue that the growth rate is not in fact responsible for the observed coefficient.

25. Some of these data were also analyzed in Frankel and MacArthur (1988). Some forward rate observations for Italy, Austria, and Belgium in the Barclay's data looked suspicious. In addition, Barclay's does not quote a rate for Portugal. For this study, forward exchange rates for Italy and Belgium are taken from the Bank of America (also obtained via DRI) and for Austria and Portugal from the Financial Times. The Barclay's data for Ireland also appear suspect (1986-88).

26. The data appendix to NBER Working Paper no. 2309 gives details.

27. The standard errors for individual country means are usable, indeed are conservative, despite the use of overlapping observations, because they are calculated as if there were $T / 3$ observations rather than the actual $T$ observations used.

28. Saving-investment regressions, by contrast, show the counterintuitive result: coefficients for LDCs that are lower (suggesting higher capital mobility, in Feldstein and Horioka's terms) than for industrialized countries. See Fieleke (1982), Dooley, Frankel and Mathieson (1987), and Summers (1988).

29 . It is possible that, for some countries, seasonal variation constitutes one forecastable component.

30. The British liberalization of 1979 is explained and analyzed in Artis and Taylor (1989).

31. As shown, e.g., by Boothe, et al. $(1985,112)$.

32. For example, Otani (1983) and Frankel (1984).

33. The frequently large negative covered differential that had been observed for Australia up to mid-1983 (see, e.g., Argy 1987) largely vanished thereafter.

34. Claassen and Wyplosz (1982), Giavazzi and Pagano (1985, 27-28), Frankel (1982), and Wyplosz (1986), among others.

35. "Capitalism," The Economist (21 May, 1988): 95.

36. For France, Italy, Ireland, Spain, and Greece (as reported in World Financial Markets, 9 September 1988, 5). Denmark's covered differential remains quite high in our sample. The country has been reported to have no capital controls left (see Economist article in n. 35), but this evidently applies only to securities: the European Commission reports that deposits and other short-term transactions remain subject to authorization in Denmark as of 1988.

37. Bahrain shows a smaller differential than the others, and even than some of the European countries with controls, like Spain and Ireland. (It should be noted that the forward rate quoted by Barclay's applies to the Saudi riyal; we match it up with the Bahraini interest rate because no local interest rate is available for Saudi Arabia and the two countries are said to be closely tied financially. The riyal is classified by the IMF under the same exchange rate arrangement as Bahrain's currency, the dinar, which would suggest that the same forward rate could be applied to both. But the riyal exchange rate does in fact vary somewhat, so that our measured covered interest differential is not entirely legitimate.)

38. Taylor (1988) is one of the most recent of many studies of covered interest parity within the London Euromarket. Such studies do not get at the degree of financial market integration across national boundaries. When authors find deviations from covered interest parity in such data (e.g., Mishkin 1984a, 1350), it is often due to low quality of the data, e.g., inexact timing. With high-quality data, Taylor finds that covered interest parity held extremely well in 1985, that it held less well in the 1970s, particularly during "turbulent" periods, that the differential had mostly vanished by 1979 , and that the differentials that do exist are slightly larger at the longer-term than shorter-term maturities. But, like other studies, Taylor has no data on maturities longer than one year.

39. It is still quite likely, however, that there is a wedge in each country separating 
the long-term interest rate from the after-tax cost of capital facing firms. Such a wedge could be due either to the corporate income tax system or to imperfect substitutability between bonds and capital. Hatsopoulos, Krugman, and Summers (1988) argue that the cost of capital facing U.S. corporation is higher than that facing Japanese corporations, even when real interest rates are equal, because U.S. companies rely more heavily on equity financing, which is more expensive than debt financing. See also papers in Feldstein (1987).

40. The results are reported in NBER Working Paper no. 2856, but are omitted here to save space.

41. The five exceptions, currencies that depreciated against the dollar at a rate more rapid than predicted by the forward discount, were the Hong Kong dollar, Malaysian ringgit, Singapore dollar, Saudi Arabian riyal, and South African rand.

42. The currencies are the Saudi Arabian riyal, and two that appreciated strongly against the dollar relative to the forward rate: the Japanese yen and the Portuguese escudo.

43. Again, the results are reported in a working paper but are omitted here.

44. Many others have found a highly significant predictable component of $\left(f d-\Delta s^{e}\right)$, often when regressing against $f d$, and particularly in sample. It is possible that such findings are not due to a time-varying premium, as the rational expectations approach would have it, but rather to a time-varying model of spot rate determination (together with insufficiently long sample periods), and learning by investors. Such speculations go outside the scope of this paper. (See Frankel and Froot 1990; and Froot and Frankel 1989.)

45. Columns (4-6) show very high variability in real depreciation, but again this tells us little about the variation of ex ante expected depreciation, beyond the observation that the high level of variability implies low power in our tests of ex ante relative purchasing power parity.

46. Once again, the results are reported in a working paper, but are omitted here.

47. It seems that in both cases an apparently predictable component of the spot rate changes constitutes most of the variation (as opposed to variation in the forward discount or inflation differential, respectively): the significant coefficients on the forward discount, interest differential, and ex post inflation differential when $\left(\Delta s-\Delta p-\Delta p^{*}\right)$ is the dependent variable are always of opposite sign and similar magnitude as the coefficients when $(f d-\Delta s)$ is the dependent variable.

48. One view is that the high degree of integration of financial markets is one of the causes of the high degree of volatility of exchange rates. The issue is discussed, and further references given, in Frankel (1988b).

\section{References}

Adler, Michael, and Bruce Lehman. 1983. Deviations from Purchasing Power Parity in the Long Run. Journal of Finance 39, no. 5: 1471-78.

Argy, Victor. 1987. International Financial Liberalisation-The Australian and Japanese Experiences Compared. Bank of Japan Monetary and Economic Studies 5, no. 1: $105-68$.

Artis, Michael, and Mark Taylor. 1989. Abolishing Exchange Control: The U.K. Experience. Centre for Economic Policy Research Discussion Paper no. 294. London, February.

Bayoumi, Tamim. 1989. Saving Investment Correlations: Immobile Capital, Govern- 
ment Policy or Endogenous Behavior? International Monetary Fund Working Paper no. $89 / 66$. Washington, D.C., August.

Bayoumi, Tamim, and Andrew Rose. 1989. Domestic Savings and Intra-National Capital Flows. Typescript. University of California, Berkeley, December.

Boothe, P., K. Clinton, A. Cote, and D. Longworth. 1985. International Asset Substitutability: Theory and Evidence for Canada. Ottawa: Bank of Canada.

Bovenberg, A. Lans. 1989. The Effects of Capital Income Taxation on International Competitiveness and Trade Flows. American Economic Review 79, no. 5: 104564.

Caprio, G., and D. Howard. 1984. Domestic Saving, Current Accounts, and International Capital Mobility. International Finance Discussion Papers no. 244. Federal Reserve Board, Washington, D.C.

Caramazza, F., K. Clinton, A. Cote, and D. Longworth. 1986. International Capital Mobility and Asset Substitutability: Some Theory and Evidence on Recent Structural Changes. Technical Report no. 44. Bank of Canada, Ottawa.

Cardia, Emanuela. 1988. Crowding Out in Open Economies. Cahier no. 8823. Université de Montreal, June.

Claassen, Emil, and Charles Wyplosz. 1982. Capital Controls: Some Principles and the French Experience. Annales de l'INSEE 47-48: 237-67.

Cumby, R., and F. Mishkin. 1986. The International Linkage of Real Interest Rates: The European-U.S. Connection. Journal of International Money and Finance 5:524.

Cumby, R., and M. Obstfeld. 1984. International Interest Rate and Price Level Linkages under Flexible Exchange Rates: A Review of Recent Evidence. In Exchange Rate Theory and Practice, ed. J. Bilson and R. Marston. Chicago: University of Chicago Press.

Darby, Michael. 1981. Does Purchasing Power Parity Work? Proceedings of the Fifth West Coast Academic/Federal Reserve Economic Research Seminar. Federal Reserve Bank of San Francisco.

1986. The Internationalization of American Banking and Finance: Structure, Risk and World Interest Rates. Journal of International Money and Finance 5, no. 4:403-28.

DeJong, David, John Nankervis, N. E. Savin, and Charles Whiteman. 1988. Integration versus Trend-Stationarity in Macroeconomic Time Series. Department of Economics Working Paper no. 88-27a. University of Iowa, December.

Dominguez, Kathryn. 1986. Expectations Formation in the Foreign Exchange Market: New Evidence from Survey Data. Economic Letters 21: 277-82.

Dooley, Michael, Jeffrey Frankel, and Donald Mathieson. 1987. International Capital Mobility: What Do Saving-Investment Correlations Tell Us? International Monetary Fund Staff Papers 34, no. 3: 503-30.

Dooley, M., and P. Isard. 1980. Capital Controls, Political Risk and Deviations from Interest-Rate Parity. Journal of Political Economy 88, no. 2:370-84.

Dornbusch, Rudiger. 1983. Real Interest Rates, Home Goods and Optimal External Borrowing. Journal of Political Economy 91.

Engel, Charles, and Kenneth Kletzer. 1989. Saving and Investment in an Open Economy with Non-traded Goods. International Economic Review 30 (November): 73552.

Feldstein, M. 1983. Domestic Saving and International Capital Movements in the Long Run and the Short Run. European Economic Review 21:139-51.

. 1987. The Effects of Taxation on Capital Accumulation. Chicago: University of Chicago Press.

Feldstein, M., and C. Horioka. 1980. Domestic Saving and International Capital Flows. Economic Journal 90:314-29. 
Fieleke, Norman. 1982. National Saving and International Investment. In Saving and Government Policy. Conference Series no. 25. Federal Reserve Bank of Boston.

Frankel, Jeffrey. 1982. On the Franc. Annales de l'INSEE 47-48: 185-221.

. 1984. The Yen/Dollar Agreement: Liberalizing Japanese Capital Markets.

Policy Analyses in International Economics, no. 9. Washington, D.C.: Institute for International Economics.

- 1986. International Capital Mobility and Crowding-out in the U.S. Economy: Imperfect Integration of Financial Markets or of Goods Markets? In How Open is the U.S. Economy? ed. R. Hafer, 33-67. Lexington, Mass.: Lexington Books.

- 1988a. International Capital Flows and Domestic Economic Policies. In The United States in the World Economy, ed. M. Feldstein. Chicago: University of Chicago Press.

- 1988b. International Capital Mobility and Exchange Rate Variability. In International Payments Imbalances in the 1980s, ed. N. Fieleke. Boston: Federal Reserve Bank of Boston.

Frankel, Jeffrey, and Kenneth Froot. 1987. Using Survey Data to Test Standard Propositions Regarding Exchange Rate Expectations. American Economic Review 77, no. 1 (March).

1990. Chartists, Fundamentalists, and the Demand for Dollars. In Private Behavior and Government Policy in Interdependent Economies, ed. A. Courakis and M. Taylor, 73-126. Oxford: Oxford University Press.

Frankel, Jeffrey, and Alan MacArthur. 1988. Political vs. Currency Premia in International Real Interest Differentials: A Study of Forward Rates for 24 Countries. European Economic Review 32.

Frenkel, Jacob. 1981. Flexible Exchange Rates, Prices and the Role of "News": Lessons from the 1970s. Journal of Political Economy 89, no. 4: 665-705.

Frenkel, J., and R. Levich. 1977. Transaction Costs and Interest Arbitrage: Tranquil versus Turbulent Periods. Journal of Political Economy 85, no. 6: 1209-26.

Froot, Kenneth, and Jeffrey Frankel. 1989. Forward Discount Bias: Is It an Exchange Risk Premium? Quarterly Journal of Economics 104:139-61.

Ghosh, Atish R. 1988. How Mobile is Capital? Some Simple Tests. Typescript. Harvard University.

Giavazzi, Francesco, and Marco Pagano. 1985. Capital Controls and the European Monetary System. In Capital Controls and Foreign Exchange Legislation, Occastional Paper. Milan: Euromobiliare.

Glick, Reuven. 1987. Interest Rate Linkages in the Pacific Basin. Economic Review, no. 3, 31-42.

Harberger, Arnold C. 1980. Vignettes on the World Capital Market. American Economic Review 70: 331-37.

Hatsopoulos, George, Paul Krugman, and Larry Summers. 1988. U.S. Competitiveness: Beyond the Trade Deficit. Science 24 (July 15): 299-307.

Huizinga, John. 1987. An Empirical Investigation of the Long Run Behavior of Real Exchange Rates. Carnegie-Rochester Conference Series on Public Policy, vol. 27.

Koraczyk, Robert. 1985. The Pricing of Forward Contracts for Foreign Exchange. Journal of Political Economy 93, no. 2: 346-68.

Krugman, Paul. 1978. Purchasing Power Parity and Exchange Rates: Another Look at the Evidence. Journal of International Economics 8, no. 3, 397-407.

Leiderman, Leo, and Assaf Razin, 1989. The Saving-Investment Balance: An Empirical Investigation. Typescript. International Monetary Fund, Washington, D.C., June.

MacArthur, Alan. 1988. International Financial Market Integration: Empirical Analysis with Data from Forward and Futures Currency Markets. Ph.D. thesis, University of California, Berkeley. 
Mark, Nelson. 1985. Some Evidence on the International Inequality of Real Interest Rates. Journal of International Money and Finance 4: 189-208.

Mishkin, Frederic. 1984a. Are Real Interest Rates Equal Across Countries? An Empirical Investigation of International Parity Conditions. Journal of Finance 39: 134558.

Mishkin, Frederic. 1984b. The Real Interest Rate: A Multi-country Empirical Study. Canadian Journal of Economics 17, no. 2: 283-311.

Morgan Guaranty Trust Company. 1988. Financial Markets in Europe: Toward 1992. World Financial Markets 5, (September 9): 1-15.

Murphy, Robert. 1984. Capital Mobility and the Relationship between Saving and Investment in OECD Countries. Journal of International Money and Finance 3: 327-342.

Obstfeld, Maurice. 1986. Capital Mobility in the World Economy: Theory and Measurement. Carnegie-Rochester Conference Series on Public Policy, 24:55-104.

Obstfeld, Maurice. 1989. How Integrated are World Capital Markets? Some New Tests. In Debt, Stabilization and Development: Essays in Memory of Carlos DiazAlejandro, ed. G. Calvo, R. Findlay, and J. de Macedo, 134-55. Oxford: Basil Blackwell.

Otani, Ichiro. 1983. Exchange Rate Instability and Capital Controls: The Japanese Experience, 1978-81. In Exchange Rate and Trade Instability: Causes, Consequences and Remedies, ed. D. Bigman and T. Taya. Cambridge, Mass.: Ballinger.

Penati, A., and M. Dooley. 1984. Current Account Imbalances and Capital Formation in Industrial Countries, 1949-1981. IMF Staff Papers 31: 1-24.

Pigott, Charles, and Richard Sweeney. 1985. In Exchange Rates, Trade and the U.S. Economy, ed. S. Arndt, R. Sweeney, and T. Willett. Washington, D.C.: American Enterprise Institute.

Popper, Helen. 1990. International Capital Mobility: Direct Evidence from Long-Term Currency Swaps. International Finance Discussion Paper no. 386. Federal Reserve Board, Washington, D.C., September.

Roll, Richard. 1979. Violations of Purchasing Power Parity and Their Implications for Efficient International Commodity Markets. In International Finance and Trade, vol. 1, ed. M. Sarnat and G. Szego. Cambridge, Mass.: Ballinger.

Roubini, Nouriel. 1988. Current Account and Budget Deficits in an Intertemporal Model of Consumption and Taxation Smoothing: A Solution to the "FeldsteinHorioka Puzzle"? Typescript. Yale University, October 1988.

Summers, L. 1986. Does the Stock Market Rationally Reflect Fundamental Values? Journal of Finance 41 (July): 591-601.

1988. Tax Policy and International Competitiveness. In International Aspects of Fiscal Policies, ed. Jacob Frenkel. Chicago: University of Chicago Press.

Taylor, Mark. 1988. Covered Interest Arbitrage and Market Turbulence: An Empirical Analysis. Centre for Economic Policy Research Discussion Paper no. 236. London.

Tesar, Linda. 1988. Savings, Investment and International Capital Flows. University of Rochester Working Paper no. 154. August.

Tobin, James. 1983. Comment on Domestic Saving and International Capital Movements in the Long Run and the Short Run," by M. Feldstein. European Economic Review 21:153-56.

Westphal, Uwe. 1983. Comments on Domestic Saving and International Capital Movements in the Long Run and the Short Run. European Economic Review 21:157-59.

Wyplosz, Charles. 1986. Capital Flows Liberalization and the EMS: A French Perspective. INSEAD Working Paper no. 86/40. European Economy, European Economic Community, June. 


\section{Comment Maurice Obstfeld}

This paper covers a broad area in its attempt to define and measure the realworld counterpart of a concept central to open-economy economic models, capital mobility. At the simplest level, one might say that capital is freely mobile between two regions when at least some residents of each are free to engage in cross-border asset trades. The potential for such trades should equalize the prices residents of the two regions are willing to pay for identical assets; but in the real world this equalization need not occur. Even within a country, for example, investors in different marginal income tax brackets may place differing values on the same asset. While such discrepancies certainly imply deviations from Pareto optimality, they may have little to do with the concept of capital mobility relevant for assessing, say, the impact of New York Fed open-market operations on California's money supply. Nor does the absence of asset-valuation discrepancies imply that physical capital will always generate the same marginal value product throughout the world.

\section{Quantifying Capital Mobility in an Idealized Economy}

Despite the questionable policy relevance of defining capital mobility in terms of an asset-valuation criterion, it is useful to start out by considering an idealized world, free of government interventions, in which contracts contingent on any state of nature can be written and costlessly enforced. Following Arrow and Debreu, one might define an asset as follows. Let there be $C$ commodities and monies, $L$ locations, and $S$ states of nature. Then an asset is an infinite sequence of three-dimensional arrays $\{p(\kappa, \lambda, \sigma ; t)\}$-where $t$ runs from tomorrow to the infinite future-in which $p(\kappa, \lambda, \sigma ; t)$ specifies the payoff $\kappa$ of a particular commodity or money to be made in location $\lambda$ in state $\sigma$ on date $t$. Under perfect capital mobility, residents of two regions should end up (in equilibrium) placing the same value on any asset. Interregional valuation discrepancies would therefore be evidence of barriers to capital movement-barriers whose origins are, perhaps, bureaucratic, cultural, or informational.

Stepping away from this rarefied setting, it is easy to see how government interventions, actual or prospective, can lead to cross-border differences in asset valuations. Take as an example of an asset a one-deutschemark deposit in Frankfurt maturing in six months. If $i_{\mathrm{DM}}$ is the six-month nominal interest rate, and if bank failure is temporarily ruled out, this asset is a promise to pay $1+i_{\mathrm{DM}}$ deutschemarks into a Frankfurt account in all states of nature six

Maurice Obstfeld is professor of economics at the University of California, Berkeley, and a research associate of the National Bureau of Economic Research.

The present written version of this comment was prepared while the author was a visiting scholar in the External Adjustment Division of the Research Department, International Monetary Fund. Research support from the Olin Foundation and the National Science Foundation is acknowledged with thanks. 
months from the deposit date. Imagine that there is some possibility that the German government will impose a regulation preventing foreigners from repatriating their interest earnings, but leaving them free to spend the interest within Germany. In general, this possibility will cause the value of Frankfurt deposits carrying a given interest rate to be lower for foreigners than for Germans. The result might be asset-market segmentation.

Frankel offers four possible definitions of perfect capital mobility, but none of them, not even covered interest parity, corresponds to the asset-valuation criterion described above. Covered interest parity between New York dollar deposits and London sterling deposits, with cover purchased in London, predicts that promises to deliver a dollar on a given date in the future in New York should sell for the same price as promises to do the same in London. This equality may or may not hold true, and its validity may or may not be related to the degree of capital mobility between New York and London. Large dollar deposits in New York and Eurodollar deposits in London may offer different payoffs in different states of nature because of more stringent prudential regulation in New York and the consequent relative instability of the Eurocurrency system. Yet an equilibrium in which investors, regardless of country of residence, attach a common value to New York deposits of a currency and attach a distinct but still common value to London deposits of the same currency is perfectly consistent with free international asset trade. ${ }^{1}$

Alternatively, however, a covered interest differential may indicate genuine barriers to capital movement, as Frankel assumes. In a country imposing significant costs on cross-border financial flows, domestic residents' valuation of any state-contingent money payment will generally differ from that of foreigners, and, as a result, onshore and offshore interest rates will generally differ as well.

Frankel's covered interest parity calculations are motivated by the desire to compare the prices of assets that are as similar as possible, except for their locations. The reasoning underlying this comparison is that, absent localityspecific risks and regulations that affect foreign and domestic residents equally, the answer one gets is close to what one would get from a comparison of different investors' valuation of the same asset. Despite the reservations just expressed, I agree with Frankel that the approach of comparing onshore with

1. Frankel's use of covered interest parity is really a roundabout way of comparing interest rates on (hopefully) similar assets that pay off in the same currency but in different locations. His tests rely on the fact that Euromarket deposits of one currency can be easily transformed into another through the forward market. As a result, one can in principle measure the interest differential between London yen and Tokyo yen, say, by comparing the London Eurodollar rate (after covering in the London dollar/yen forward market) with the Gensaki rate. The practical problem with Frankel's method is that it introduces additional measurement errors when the forward premium and interest rates are measured at different times, as is apparently the case in this study. I would therefore prefer, when possible, to work directly with Euroyen rather than covered Eurodollar interest rates. 
offshore interest rates is the most reliable method available for quantifying impediments to capital movement. I adopted essentially the same approach in my 1986 paper (Obstfeld 1986), and also reached the conclusion that the degree of financial integration among industrial countries is now very high. But I hope the present discussion makes clear how approximate an answer interest-rate comparisons yield.

\section{Capital Mobility and Economic Policy: The Case of Crowding Out}

While the asset-valuation measure of capital mobility offered above may be useful for a detailed theoretical analysis of economic efficiency, it is less useful for addressing many questions of macroeconomic interest. The problem is that to analyze the effects of policies, it is not enough to know only that investors in different countries value some identical assets differently. One usually needs to know, in addition, why investors' valuations of the assets differ.

A simple example focuses on the question of crowding out, which motivated the Feldstein-Horioka (1980) study. Feldstein and Horioka reasoned that, under perfect capital mobility, changes in a country's saving rate should not affect its investment rate. Because investment projects can be financed out of a global pool of internationally mobile savings, saving shifts within a particular country should not crowd out (or crowd in) domestic investment.

Consider a small country that would be a capital importer under laisserfaire. ${ }^{2}$ The assumption that this country would run a deficit on current account under free asset trade means that, in the presence of restrictions on foreign borrowing, its interest rate exceeds the world interest rate. The observation that the interest rate its residents face differs from that faced by foreigners is not enough to determine whether a fall in national saving would crowd out domestic investment. Two possible situations are (1) the country's government has imposed a nonprohibitive tariff on capital imports and (2) the government has placed a binding quantitative limit on capital imports. In either of these cases, the domestic interest rate is above the world interest rate. But in case 1 , a small fall in national saving has no crowding out effect at all; in a certain sense, capital remains fully mobile at the margin despite the international interest differential. In contrast, a decline in saving crowds out investment point for point in case 2 .

Even if potential interest-arbitrage opportunities are absent, or if the causes generating them are known, policy effects obviously may still depend on the economy's structure. An economy large enough to affect the world interest rate will show a different degree of crowding out than a small economy. As

2. For the purpose of this example, think of a world with one commodity on each date. Then "the" real interest rate is just the price of present output in terms of future output, less one. (International real interest differentials, to be discussed below, can arise in this setting only as a result of impediments to international asset trade.) The underlying model $I$ have in mind here is Irving Fisher's two-period model of investment and saving under conditions of full employment. 
Frankel notes, an economy where the expected real interest rate varies with goods-market prices may behave differently from one in which purchasing power parity holds ex ante.

In attempts to determine empirically such parameters as the degree of crowding out in an open economy, asset-valuation comparisons can therefore be beside the point, if not misleading. In most cases, a direct econometric attack on the problem of interest is preferable. As Frankel's own analysis of crowding out indicates, however, the design of appropriate estimation strategies may not be easy.

Feldstein and Horioka (1980) were the first to attempt to measure the degree of crowding out by regressions of investment rates on saving rates. Their finding of near-unit coefficients (a result weakened by more recent data) reflected a stylized fact that calls out for explanation, the typically small sizes of current-account imbalances in the postwar period through the early 1980s. Their interpretation of the finding, that imperfect capital mobility causes most of a change in saving to be reflected in the home capital stock, has been widely criticized. My 1986 paper made the theoretical argument that even under capital mobility, high saving-investment correlations could result from common factors affecting both saving and investment at the same time. Later on I evaluate Frankel's claim that the most important common factor is the domestic real interest rate.

Frankel apparently rejects the view that investment-saving regressions measure capital mobility, but he accepts them as a valid way to measure the effect of exogenous shifts in saving on investment, provided instrumental variables are used to correct for the endogeneity of saving. ${ }^{3} \mathrm{He}$ interprets time-series regressions based on U.S. saving and investment data as evidence that for the United States, the crowding out effect has become dramatically smaller over the past decade.

\section{A Model of Saving and Investment}

It is difficult to evaluate Frankel's interpretation of the regression results outside the context of a specific model. One standard model shows quite easily that Frankel's estimated coefficients need not consistently measure the degree of crowding out, despite the use of exogenous instrumental variables correlated with saving. Further, the coefficients estimated are vulnerable to the Lucas critique: they change with changes in the stochastic processes driving the model's exogenous variables. This vulnerability makes the estimates potentially unstable and thus particularly misleading as guides to policy.

My exemplary full-employment model is a variant of one used for a similar purpose by Feldstein (1983), though the original source is probably Metzler

3. This procedure was proposed in Frankel (1986). Frankel also attempts to adjust for cyclical factors that simultaneously affect saving and investment. 
(1960). If $r$ is the domestic real interest rate and $u$ an exogenous disturbance, then the share of saving in output is given by

$$
S_{t} / Y_{t}=a x_{t}+b r_{t}+u_{t},
$$

where all variables are deviations from (unconditional) means and coefficients are positive. In equation (1), the variable $x$ is Frankel's instrumental variable, which influences saving but is uncorrelated with all the model's disturbances. The investment rate depends on $r$ plus an investment shock $v$,

$$
I_{t} / Y_{t}=-d r_{t}+v_{t} \text {. }
$$

Capital inflows are modeled so as to reflect the possibility of imperfect mobility. Let $r^{*}$ be an exogenously varying world real interest rate, expressed in terms of foreign output. If $q$ is the relevant real exchange rate (the price of foreign output in terms of domestic, expressed as a natural logarithm), then desired net capital inflows (scaled by output) should depend on the difference between the domestic real interest rate $r$ and the expected rate of return on foreign investment expressed in terms of domestic output,

$$
K_{t} / Y_{t}=f\left[r_{t}-r_{t}^{*}-E_{t}\left(q_{t+1}-q_{t}\right)\right]+w_{t},
$$

where $w$ is an exogenous disturbance to capital inflows. As $f$ grows arbitrarily large, the condition

$$
r_{t}=r_{t}^{*}+E_{t}\left(q_{t+1}-q_{t}\right),
$$

which defines perfect capital mobility in this model, is approached.

Finally, the current-account surplus is modeled as a function of the contemporaneous real exchange rate and an international-trade shock $z$,

$$
C A_{t} / Y_{t}=e q_{t}+z_{t} \text {. }
$$

In equilibrium, any current account imbalance must be financed by net capital flows, so

$$
C A_{t}+K_{t}=0 .
$$

To close the model, one supplements this requirement of flow consistency in the balance of payments with the output-market equilibrium condition:

$$
S_{t}-I_{t}=C A_{t} \text {. }
$$

The foregoing model neglects some important dynamic elements, such as the intrinsic dynamics due to cumulating asset stocks or possible lagged current-account adjustment to real exchange-rate changes. It is nevertheless useful as kind of first-order approximation, one that hopefully captures the main factors behind medium-term comovements of interest rates, real exchange rates, and the saving-investment balance. 


\section{The Model's Solution}

The equilibrium real exchange rate is found using the usual solution technique for rational-expectations models. Define the composite disturbance $n$, as

$$
\begin{aligned}
n_{t}= & r_{t}^{*}+\left(a x_{t}+u_{t}-v_{t}\right) /(b+d) \\
& -w_{t} / f-(b+d+f) z_{t} / f(b+d),
\end{aligned}
$$

and define the parameter $h$ as $h=(b+d) /[(b+d)+(e / f)(b+d+f)]$. Then (5) and (6) imply that the real exchange rate is a convergent infinite sum,

$$
q_{t}=h\left[n_{t}+h E_{t}\left(n_{t+1}\right)+h^{2} E_{t}\left(n_{t+2}\right)+h^{3} E_{t}\left(n_{t+3}\right)+\ldots\right] .
$$

As usual, the relation of $q_{t}$ to the exogenous shocks that define the composite variable $n_{t}$ depends on the serial-correlation properties of those shocks. To illustrate the pitfalls in Frankel's estimation approach, however, I assume for now that the instrumental variable $x$ follows a martingale process, and therefore is rationally expected to remain at its current level; all other random variables on the right-hand side of (7) are assumed to be white noise. Under these assumptions,

$$
q_{t}=(f / e){a x_{t}}_{t} /(b+d+f)+\left(\text { terms in } r_{t}^{*}, \text { etc. }\right),
$$

and (by [5]) the domestic real interest rate is

$$
r_{t}=-a x_{t} /(b+d+f)+\text { (terms in } r_{t}^{*} \text {, etc.). }
$$

Solution (9) may now be combined with equations (1) and (2) to find the reduced-form saving and investment equations,

$$
\begin{gathered}
S_{t} / Y_{t}=(d+f) a x_{t} /(b+d+f)+\left(\text { terms in } r_{t}^{*}, \text { etc. }\right) \\
I_{t} / Y_{t}=\operatorname{dax}_{t} /(b+d+f)+\left(\text { terms in } r_{t}^{*}, \text { etc. }\right) .
\end{gathered}
$$

Equation (11) makes transparent the effect of an exogenous and permanent shift in saving on the investment rate. Given the specification (1), an exogenous shift in saving can arise from a permanent shift in $a x_{t}$ or in $u_{t}$. The variable $a x_{t}$, changes in which are permanent, carries the coefficient $d /(b+d+f)$ in (11), so this coefficient tells us, for example, the amount of investment crowded out by a permanent autonomous decline in the saving rate. Notice that even under complete capital immobility $(f=0)$, crowding out is less than complete provided saving is interest sensitive $(b>0)$. The reason is that an exogenous negative saving shift raises the home interest rate, causing equilibrium saving (and hence investment) to fall by less. ${ }^{4}$ Under per-

4. This fact shows, already, that one cannot interpret a simple saving-investment correlation as measuring the extent of crowding out. Even in an economy where capital controls lead to a perfect correlation between saving and investment, the effect on investment of an exogenous saving shift is reduced by a partially offsetting change in the endogenous, interest-sensitive component of saving. 
fect capital mobility (an infinite $f$ ), however, exogenous shifts in saving do not affect investment provided the shifts are permanent.

Do the Instrumental-Variable Estimates Measure Crowding Out?

We can now ask whether an instrumental-variable (IV) regression of investment on saving produces a consistent estimate of the policy coefficient of interest, $d /(b+d+f)$. Equations (10) and (11) lead to a clear negative answer for the present model.

This can be seen as follows. If the instrumental variable $x$ is uncorrelated with all the model's disturbances, as Frankel assumes, and with the world interest rate $r^{*}$, then (10) shows that a first-stage regression of $S / Y$ on $x$ yields a consistent estimate of the coefficient $(d+f) a /(b+d+f)$. The reduced form equation for investment, (11), therefore can be rewritten as

$$
I_{t} / Y_{t}=[d /(d+f)]\left(S \hat{Y} Y_{t}\right)+\left(\text { terms orthogonal to } x_{t}\right),
$$

where $\left(S_{t} \hat{t} Y_{t}\right)$ is the fitted value from the first-stage regression of $S / Y$ on $x$.

Equation (12) is the regression that is run to obtain the IV estimate of the crowding out coefficient, $d /(b+d+f)$; however, the resulting estimate clearly converges in probability, not to $d /(b+d+f)$, but to the larger number $d /(d+f)$. The econometric pitfalls of regressing investment on saving apparently go deeper than the observation that saving needs an exogenous instrument. Here, an issue of equation specification is also involved. The "structural" equation for $I / Y$ in which $S / Y$ appears on the right-hand side with coefficient $d /(b+d+f)$ also involves $x$ as a separate regressor. The implication is that $x$ is not really a valid instrument for the purpose at hand, despite its lack of correlation with the model's disturbances. ${ }^{5}$

The following conclusions can be drawn from this analysis: (1) IV estimates such as those Frankel presents may overstate the degree to which exogenous saving shifts affect investment. This overstatement is large when $d$ and $f$ are small relative to $b$. (2) There are some special cases in which IV is appropriate in the above example. One occurs when saving is not interest sensitive $(b=0)$, a situation many view as plausible on empirical, if not on theoretical, grounds. (In the present model, the saving rate is an exogenous variable if $b=0$.) The IV method is also appropriate when investment is not interest sensitive $(d=0)$, but in this case exogenous saving shifts leave investment unchanged regardless of the degree of capital mobility. Finally, the IV estimator "works" in this specific example if one wishes to test the null hypothesis of perfect capital mobility (an infinite $f$ ). But if that hypothesis is rejected, inferences about crowding out require additional information. (3) Changes over time in the IV coefficient do reflect changes in the degree of capital mobility and in the degree of crowding out-other things the same. If

5. Equivalently, the crowding-out coefficient is not generally identified (despite the availability of $x$ ) under the present assumptions. 
$f$, rises, for example, both the degree of crowding out and the IV coefficient fall. (4) One should not take the calculation above too literally as an indication of the biases due to IV estimation. In reality, shocks to $x$ may be transitory; the instrument $x$ may be correlated with the world interest rate $r^{*}$; or some model other than the one sketched above may be relevant. Any of these departures from my simplifying assumptions would change the analysis.

As an illustration of point 4, imagine that the instrumental variable $x$ follows the first-order autoregression $x_{t}=\rho x_{t-1}+\varepsilon_{t}$, with $\rho$ strictly between 0 and 1 and $E_{t-1}\left(\varepsilon_{t}\right)=0$. In this case, shifts in $x$ are not perceived as permanent. The reduced-form coefficients of $x$ in the equations explaining $S / Y$ and $l / Y$ therefore differ from the ones shown in (10) and (11), and can no longer be interpreted as measures of the effects of permanent changes in $x$. Instead, these coefficients reflect the actual persistence of innovations in $x$ in the historical sample. This is just an instance of the Lucas critique: without knowledge of structural parameters, it is not generally possible to infer from the reduced-form coefficients the effects of permanent shifts in the instrumental variable $x$.

One might still be interested in knowing the amount of investment crowded out over the sample period by innovations to $x$. It is easy to show that, once again, the IV estimate overstates the true figure when $b>0$. With $x$ a stationary process, however, this overstatement occurs even when capital mobility is perfect. Furthermore, the IV coefficient now is not asymptotically zero under perfect capital mobility, so one cannot test that hypothesis by looking for a zero coefficient. ${ }^{6}$

The main message of the example is that the existence of exogenous "instruments" correlated with saving is no panacea in cases of underidentification. This message applies to cross-section as well as time-series estimation.

\section{Real Interest Rates, Saving, and Investment}

Regardless of one's interpretation of investment-saving regressions, their results, as noted above, point to an intriguing empirical regularity: from the end of World War II up until the early 1980s, current-account deficits tended to be quite small compared with national income. Even in the 1980s, major industrial countries' current-account imbalances have not surpassed the levels sustained by Great Britain in the decades leading up to World War I. Alternative solutions to this "Feldstein-Horioka puzzle" have sharply different implications for policy. Presumably, a good explanation should throw light on both the short-run time-series behavior of current accounts and the cross-sectional coincidence of saving and investment over longer time spans.

Frankel's favorite approach rests on the observation that real interest rates

6. Because it is unlikely that the $x$ process would remain stable over a very long period, it is also unlikely that the IV regression coefficient would be stable. This mechanism, rather than shifts in capital mobility, could be the main factor behind the striking coefficient instability reported in this paper and in Frankel (1986). 
can differ across countries even when there is uninhibited international asset trade. The undeniable fact of real interest differentials does not, however, offer an automatic explanation of the Feldstein-Horioka results. Think again about the saving-investment model set out above, and consider the case of perfect capital mobility.

The model certainly allows for real interest differentials, yet permanent disturbances do not give rise to them under perfect capital mobility. This result would be attenuated a bit if the model were expanded in a way that endogenized the process of asset accumulation; but it is probably not a bad approximation to say that permanent shocks have slight effects, compared with temporary ones, on the rationally expected change in the real exchange rate.

Because of their more powerful short-run effect on the real interest rate, temporary disturbances can give rise to high correlations between saving and investment. For example, if $x$ in (1) follows a first-order autoregression with positive autoregressive coefficient $\rho$, the IV slope coefficient analyzed above converges to $d(1-\rho) /[d(1-\rho)+e]$ under perfect capital mobility. This coefficient is close to unity when $e$ (the current-account effect of the real exchange rate) is small, and it is larger the smaller the degree of persistence $\rho$.

The foregoing result is still not enough to resolve the Feldstein-Horioka puzzle. While temporary shocks to $x, u$, or $v$ cause saving and investment to covary positively, other temporary shocks cause negative covariation. A temporary positive shock to the trade balance ( $z$ in equation [4]) increases the domestic real interest rate and therefore causes saving to rise and investment to fall. Monetary shocks, if formally introduced into the model, could also cause saving and investment to move in opposite directions. To explain observed time-series correlations between saving and investment on the basis of real interest differentials, one must therefore argue that direct shocks to the saving and investment schedules not only display low persistence, but also are the dominant sources of fluctuations.

A solution to the Feldstein-Horioka puzzle based on temporary shocks to saving and investment is deficient in another respect. Since temporary shocks tend to offset each other over time, they cannot explain the high crosssectional correlation between long time-averages of saving and investment rates. To apply the real-interest explanation to the cross-section findings, one would need (at the very least) an empirically significant mechanism through which persistent shifts in saving or investment rates have persistent effects on real interest rates under capital mobility. Stories can certainly be told, but a convincing case has yet to be made. I doubt that any single mechanism, out of the many that have been proposed, provides a full answer to the puzzle.

\section{References}

Feldstein, Martin. 1983. Domestic saving and international capital movements in the long run and the short run. European Economic Review 21: 129-51. 
Feldstein, Martin, and Charles Horioka. 1980. Domestic saving and international capital flows. Economic Journal 90: 314-29.

Frankel, Jeffrey A. 1986. International capital mobility and crowding-out in the U.S. economy: Imperfect integration of financial markets or of goods markets? In How open is the U.S. economy?, ed. R. W. Hafer. Lexington, Mass.: Heath.

Metzler, Lloyd A. 1960. The process of international adjustment under conditions of full employment: A Keynesian view. Typescript. (Reprinted in Readings in international economics, ed. R. E. Caves and H. G. Johnson. Homewood, Ill.: Irwin, 1968.)

Obstfeld, Maurice. 1986. Capital mobility in the world economy: Theory and measurement. Carnegie-Rochester Conference Series on Public Policy 24: 55-103. 